\title{
The Challenge of Communicating with the Consumer and Validating the Debt Under the Fair Debt Collection Practices Act
}

\author{
Elwin Griffith ${ }^{*}$
}

\section{INTRODUCTION}

Congress enacted the Fair Debt Collection Practices Act (FDCPA) ${ }^{1}$ in 1977 to regulate the conduct of debt collectors. ${ }^{2}$ It was not a surprising development, given the incredible stories about misconduct in the collection industry. ${ }^{3}$ Witnesses at the congressional hearings recounted the strategies that debt collectors used to achieve their objective, including telephone harassment and threats of reprisals for unpaid bills. ${ }^{4}$ These tactics were all the more regrettable since most consumers did not default on their obligations with any intent to defraud their creditors, but instead found themselves in difficulty because of

Tallahassee Alumni Professor, Florida State University College of Law. (2000)).

1. Pub. L. No. 95-109, 91 Stat. 874 (1977) (codified as amended at 15 U.S.C. $\S \S 1692-16920$

2. Its purpose was to "eliminate abusive debt collection practices by debt collectors, to insure that those debt collectors who refrain from using abusive debt collection practices are not competitively disadvantaged, and to promote consistent State action to protect consumers against debt collection abuses." 15 U.S.C. $§ 1692(\mathrm{e})$.

3. The Senate Report on the FDCPA reflected some of the problems as follows:

Collection abuse takes many forms, including obscene or profane language, threats of violence, telephone calls at unreasonable hours, misrepresentation of a consumer's legal rights, disclosing a consumer's personal affairs to friends, neighbors, or an employer, obtaining information about a consumer through false pretense, impersonating public officials and attorneys, and simulating legal process.

S. Rep. No. 95-382, at 2 (1977), reprinted in 1977 U.S.C.C.A.N. 1695, 1696.

4. One witness provided the following perspective of the collection abuses:

While debt collection agencies generate numbers of complaints disproportionate to their size in the American economy, the most disturbing aspect of consumer grievances generated by collection agencies is the type of conduct which is complained about. This conduct, ranges from profanity and obscenity in phone calls to efforts to shame a consumer by contacting relatives, employers, neighbors to falsely threatening to seek harsh legal sanctions.

Fair Debt Collection Practices Act: Hearings on S. 656, S. 1130 and H.R. 5294 Before the Subcomm. on Consumer Affairs of the S. Comm. on Banking, Housing and Urban Affairs, 95th Cong. 85, 85 (1977) [hereinafter Hearings] (statement of Robert J. Hobbs, Staff Attorney, National Consumer Law Center). 
unforeseen circumstances. ${ }^{5}$ The average defaulting debtor faced unrelenting debt collectors who left no stone unturned in their quest for payment. ${ }^{6}$

In drafting the FDCPA, Congress had to balance the interests of collectors and consumers, since it was evident that the vast majority of collectors did the right thing and were not abusive and deceptive in their collection efforts. ${ }^{7}$ Congress tried to reach a happy medium, but nevertheless, questions eventually arose about a collector's obligations and the meaning of certain language in the legislation.

There is no shortage of troublesome terms in the FDCPA. The term "communication" 8 appears frequently in the statute and has assumed an importance all its own. This Article will consider the context in which communication can occur between a consumer and a collector. It will be evident that problems arise because a communication may be oral or written. ${ }^{9}$ When the statute provides for a collector's disclosure of certain information in an initial communication with the consumer, or within five days thereafter, ${ }^{10}$ it raises questions that have no easy answer.

5. Professor Caplovitz gave some idea of the reasons why consumers default:

As my research has shown, the collection industry's image of the default debtor as a deadbeat is a grotesque caricature that has virtually nothing to do with the realities of why debtors default.

Of the 1331 debtors in default that we interviewed, no more than 4 per cent, that is, one in every twenty-five, corresponded to the classic image of the deadbeat. And even in this tiny group, only a few entered the transaction with the deliberate intention to defraud the creditor. Many more in this small group decided to stop paying when some untoward event occurred. A number had their marriages turn sour and they decided to stop paying on their debts as they suddenly felt their lives falling apart. Familial instability is thus another factor contributing to breakdowns in credit transactions.

Hearings, supra note 4, at 238, 243 (testimony of Professor David Caplovitz, City University of New York).

6. One state official recounted a consumer's experience with a debt collector: "They telephoned up to 40 times a day, ringing back as soon as we hung up. The constant and pointless telephone calls caused us considerable worry and anxiety, not only because the collector was rude and insulting, but also because our business phone was virtually put out of commission." Id. at 619 (testimony of Thomas Tahnk, Supervisor, Collection Agency Division, Minnesota Office of Consumer Services).

7. The Senate Report recognized the problem: "While unscrupulous debt collectors comprise only a small segment of the industry, the suffering and anguish which they regularly inflict is substantial." S. Rep. No. 95-382, at 2, reprinted in 1977 U.S.C.C.A.N. at 1696.

8. The FDCPA defines "communication" as "the conveying of information regarding a debt directly or indirectly to any person through any medium." 15 U.S.C. $§ 1692 \mathrm{a}(2)$ (2000).

9. See id. (defining "communication" as occurring "through any medium").

10. The statute requires a debt collector to provide certain information about the debt as follows:

Within five days after the initial communication with a consumer in connection with the collection of any debt, a debt collector shall, unless the following information is 
Foremost among them is whether Congress could have intended that a collector convey orally to the consumer the details of the debt and the consumer's right to dispute it, with the expectation that the consumer would easily digest the information. ${ }^{11}$

Another question that has provoked some judicial disagreement relates to legal pleadings. ${ }^{12}$ If they constitute a communication, then they are subject to the normal rules relating to the right of a consumer to seek verification of the debt. ${ }^{13}$ The constituencies that argue for excluding a summons and complaint from the definition of "communication" do so with some nostalgia about the days when lawyers enjoyed an exemption from the FDCPA. $^{14}$ Even though such an exemption has long

contained in the initial communication or the consumer has paid the debt, send the consumer a written notice containing-

(1) the amount of the debt;

(2) the name of the creditor to whom the debt is owed;

(3) a statement that unless the consumer, within thirty days after receipt of the notice, disputes the validity of the debt, or any portion thereof, the debt will be assumed to be valid by the debt collector;

(4) a statement that if the consumer notifies the debt collector in writing within the thirty-day period that the debt, or any portion thereof, is disputed, the debt collector will obtain verification of the debt or a copy of a judgment against the consumer and a copy of such verification or judgment will be mailed to the consumer by the debt collector; and

(5) a statement that, upon the consumer's written request within the thirty-day period, the debt collector will provide the consumer with the name and address of the original creditor, if different from the current creditor.

15 U.S.C. $\S 1692 \mathrm{~g}(\mathrm{a})(2000)$.

11. The problem arises because the statute gives a debt collector an option. The collector may provide the information required by $\S 1692 \mathrm{~g}$ (a) either in its initial communication (which need not be written), or in a written notice within five days thereafter. The Federal Trade Commission (FTC) Staff Commentary provides that "[i]f a debt collector's first communication with the consumer is oral, he may make the disclosures orally at that time in which case he need not send a written notice." FTC Staff Commentary on the Fair Debt Collection Practices Act, 53 Fed. Reg. 50,097, 50,108 (Dec. 13, 1988) [hereinafter FTC Staff Commentary]. The FTC Staff publishes its interpretations of the FDCPA in its Commentary, but the Commentary does not have the force or effect of the statute and is not binding on the FTC or the public. Id. at 50,101. Nevertheless, the Commentary is helpful in understanding the statute.

12. Compare Thomas v. Law Firm of Simpson \& Cybak, 392 F.3d 914, 920 (7th Cir. 2004) (en banc) (holding that summons and complaint do constitute an initial communication under FDCPA), with Vega v. McKay, 351 F.3d 1334, 1337 (11th Cir. 2003) (per curiam) (holding that summons and complaint do not constitute an initial communication under FDCPA).

13. The collector must inform the consumer in the "initial communication," or within five days thereafter, of the right to seek verification of the debt. 15 U.S.C. $\S 1692 \mathrm{~g}(\mathrm{a})$

14. In Vega, the Eleventh Circuit relied on the FTC Staff Commentary which stated that the institution of legal action was not a communication. See 351 F.3d at 1336-37 (citing FTC Staff Commentary, supra note 11, at 50,108). This nonbinding FTC interpretation preceded the Supreme Court's decision in Heintz v. Jenkins, 514 U.S. 291, 299 (1995), which held that the FDCPA applies to lawyers who regularly collect debts through litigation. The Court in Heintz highlighted the fact that Congress had withdrawn the FDCPA exemption for lawyers and had not replaced it with any litigation-related provision. Id. at 294-95. 
disappeared, ${ }^{15}$ some debt collectors share the nagging feeling that litigation enjoys a special place in the scheme of things, and that a summons and complaint should not be subject to the FDCPA. ${ }^{16}$ This Article will discuss the divisions on this matter and will suggest that there is more legislative work to be done if a summons and complaint are not to be regarded as a communication.

This Article will also review some of the strategies employed by enterprising debt collectors. ${ }^{17}$ When it is not an attorney threatening legal action, ${ }^{18}$ it is someone else trying to convince a consumer that an attorney will soon be involved, and that it is advantageous for the consumer to settle the matter promptly. ${ }^{19}$ The cases will show how far a debt collector can go in trying to realize its objective of recovering the debt. Quite often it is the subtlety of the language that leads to a consumer's distress, and it is then a court's assignment to distinguish between a bizarre interpretation and a reasonable construction of the collection letter. Other problems arise when a collector leaves no stone unturned in exaggerating the amount of the debt by including fees and costs not yet due. ${ }^{20}$ The collector's strategy in this context is to create a

15. See Pub. L. No. 99-361, 100 Stat. 768 (1986) (amending section 803(6) of the Fair Debt Collection Practices Act (15 U.S.C. § 1692a(6) (1982)).

16. In Thomas v. Law Firm of Simpson \& Cybak, the defendants contended that treating a summons and complaint as an "initial communication" would create problems "by making debt collection lawsuits more cumbersome for attorneys." 392 F.3d at 918. The Supreme Court had rejected similar arguments in Heintz v. Jenkins. See 514 U.S. at 296-97 (holding that a court-related document qualifies as a communication).

17. The FDCPA forbids a collector to use any "false, deceptive, or misleading representation or means in connection with the collection of any debt." 15 U.S.C. $\S 1692 \mathrm{e}(2000)$. Without limiting the application of that general language, the section then describes sixteen examples of prohibited conduct. Id. $\S 1692 \mathrm{e}(1)-(16)$.

18. See Graziano v. Harrison, 950 F.2d 107, 111 (3d Cir. 1991) (threat of immediate legal action if debt not paid within ten days was a violation); Crossley v. Lieberman, 868 F.2d 566, 571 (3d Cir. 1989) (holding that threat to take legal action that debt collector did not intend to take was a violation); Goins v. JBC \& Assocs., P.C., 352 F. Supp. 2d 262, 272 (D. Conn. 2005) (threat to sue was improper); Edwards v. McCormick, 136 F. Supp. 2d 795, 806 (D. Ohio 2001) (finding that attorney threatened action he could not legally take).

19. See Goswami v. Am. Collections Enter., Inc., 377 F.3d 488, 496 (5th Cir. 2004) (holding that settlement offers must be nondeceitful); Pipiles v. Credit Bureau, Inc., 886 F.2d 22, 25-26 (2d Cir. 1989) (holding that threat of legal action the collector did not intend to take constitutes a violation of $\S \S 1692 \mathrm{e}(5)$ and (10)); Schimmel v. Slaughter, 975 F. Supp. 1357, 1363 (M.D. Ga. 1997) (holding that collection letter falsely implied that file had been turned over to attorney whose private practice was separate from the credit bureau).

20. See Veach v. Sheeks, 316 F.3d 690, 693 (7th Cir. 2003) (where a debt collector sought treble damages from debtor who wrote a bad check); Pollice v. Nat'l Tax Funding, L.P., 225 F.3d 379, 387 (3d Cir. 2000) (where a debt collector sought unusually high interest and penalties); Duffy v. Landberg, 215 F.3d 871, 873 (8th Cir. 2000) (where debt collector overstated interest charges in collection letters); Padilla v. Payco Gen. Am. Credits, Inc., 161 F. Supp. 2d 264, 270 (S.D.N.Y. 2001) (where a debt collector sought to collect attorney's fees from the debtor); Ballard v. Equifax Check Servs., 158 F. Supp. 2d 1163, 1167 (E.D. Cal. 2001) (where an authorization and guarantee 
sense of hopelessness in the consumer, who may then be willing to meet the collector halfway in order to settle the debt. The tendency of the courts is to insist on certainty as to the amount due as of the date of the collector's letter, without detracting from the collector's ability to explain the circumstances under which the amount might change. ${ }^{21}$

There is another provision in the FDCPA that commands attention. It is $\S 1692 \mathrm{~g}$, requiring a debt collector to notify the consumer that if the consumer disputes the debt in writing, the debt collector will seek verification thereof from the creditor. ${ }^{22}$ It is fair to say that there are frequent disagreements over the validation section, since a debt collector usually wants to press on with its debt recovery efforts, while advising the consumer about his validation rights. There is nothing in the statute that requires the collector to suspend its activities during the thirty days granted to the consumer for disputing the debt, because that period is not a grace period. ${ }^{23}$ Nevertheless, as the cases will show, courts are constantly struggling to strike a happy medium between the consumer's right to dispute the debt and the collector's right to send an effective collection message in the same communication. ${ }^{24}$ It seems as if this struggle will continue unless Congress amends the statute with a view to relieving the tension between the competing interests of collectors and of consumers. This Article will consider the problems that are inherent in the present statutory language. It will also discuss the difficulty of

service sought to collect a twenty-dollar returned check fee in violation of the FDCPA).

21. See Miller v. McCalla, Raymer, Padrick, Cobb, Nichols, \& Clark, L.L.C., 214 F.3d 872, 876 (7th Cir. 2000) (holding that a debt collector has a duty to state the amount of the debt owed); Bartlett v. Heibl, 128 F.3d 497, 502 (7th Cir. 1997) (holding that debt collection letters cannot be confusing); McDowall v. Leschack \& Grodensky, P.C., 279 F. Supp. 2d 197, 199, 200 (S.D.N.Y. 2003) (holding that a collector violated FDCPA by not stating the amount of interest owed and by including attorney's fees in the balance due).

22. 15 U.S.C. $\S 1692 \mathrm{~g}(\mathrm{a})(4)(2000)$

23. The statute requires the collector to cease collection activities only if the consumer disputes the debt in writing within thirty days after receiving the validation notice. Id. $\S 1692 \mathrm{~g}(\mathrm{~b})$. The collector may then resume activities once it mails the verification information to the consumer. Id. The FTC does not regard the thirty-day dispute period as a grace period. Mezines, FTC Advisory Opinion (Mar. 31, 2000), http://www.ftc.gov/os/2000/04/fdcpaadvisoryopinion.htm [hereinafter Advisory Opinion].

24. See Shimek v. Forbes, 374 F.3d 1011, 1014 (11th Cir. 2004) (holding that a debt collector could send a dunning letter to a debtor at the same time it filed a lien with the clerk of court); McStay v. I.C. Sys., Inc., 308 F.3d 188, 191 (2d Cir. 2002) (holding that an ambiguity later clarified did not violate the FDCPA notice provision); United States v. Nat'l Fin. Servs., 98 F.3d 131, 139 (4th Cir. 1996) (holding that a notice on the back of a collection letter was not false or deceptive); Gervais v. Riddle \& Assocs., 363 F. Supp. 2d 345, 355 (D. Conn. 2005) (holding that communications from the debt collector were false and misleading and that collection letter contradicted and overshadowed validation notice). 
reconciling the absence of a writing requirement in $\S 1692 \mathrm{~g}(\mathrm{a})(3)$ with the presence of such a requirement in $\S 1692 \mathrm{~g}(\mathrm{a})(4) .^{25}$

Finally, the Article will conclude with a discussion of two provisions that prohibit a debt collector from engaging in unfair practices to collect a debt. The first one relates to the kind of language that a collector may use on an envelope when it communicates with a consumer, ${ }^{26}$ and the second concerns the controls that are in place to regulate a collector's nonjudicial action to repossess property that is under the consumer's control. ${ }^{27}$

\section{THE ELEMENT OF COMMUNICATION}

\section{A. The Importance of the Term}

There is hardly ever any disagreement about the importance of communication in the commercial world. In the debt collection business, communication is sometimes encouraged, other times forbidden. ${ }^{28}$ But the courts must decide whether there has been any communication between a debt collector and a debtor before imposing any liability on the debt collector under the FDCPA.

The FDCPA defines "communication" as "the conveying of information regarding a debt." 29 With certain exceptions, a collector must not communicate with third parties about a consumer's debt unless it is seeking information about a debtor's location. ${ }^{30}$ On the other hand, a collector must give a debtor, in its initial communication or within five days thereafter, notice of the right to dispute the debt and must provide

25. Section $1692 \mathrm{~g}(\mathrm{a})(3)$ allows a collector to assume that a debt is valid if the consumer does not dispute the validity of the debt within thirty days after receiving a validation notice. 15 U.S.C. $\S$ $1692 \mathrm{~g}(\mathrm{a})(3)$. On the other hand, $\S 1692 \mathrm{~g}(\mathrm{a})(4)$ requires a consumer to dispute the debt in writing if he wants the collector to seek verification from the creditor. $I d$. $\$ 1692 \mathrm{~g}(\mathrm{a})(4)$.

26. 15 U.S.C. $\S 1692 \mathrm{f}(8)(2000)$.

27. Id. $\S 1692 \mathrm{f}(6)$.

28. Compare 15 U.S.C. $§ 1692 \mathrm{c}$ (2000) (forbidding communication except in certain circumstances), with 15 U.S.C. $\$ 1692 \mathrm{~g}($ a) (requiring validation notice).

29. 15 U.S.C. $\S 1692 \mathrm{a}(2)(2000)$.

30. Section $1692 \mathrm{c}(\mathrm{b})$ provides as follows:

Except as provided in section $1692 \mathrm{~b}$ of this title, without the prior written consent of the consumer given directly to the debt collector, or the express permission of a court of competent jurisdiction, or as reasonably necessary to effectuate a postjudgment judicial remedy, a debt collector may not communicate, in connection with the collection of any debt, with any person other than the consumer, his attorney, a consumer reporting agency if otherwise permitted by law, the creditor, the attorney of the creditor, or the attorney of the debt collector.

15 U.S.C. $\S 1692 c(b)$. 
other details required by the validation provision. ${ }^{31}$ It is important to fix the time of communication because that is the marker for determining when a collector must give the debtor the required validation notice. In the first place, the statute does not require that a communication must be in writing to be valid. ${ }^{32}$ This means, therefore, that a collector can include all of the information required by $\S 1692 \mathrm{~g}$ in its initial communication even if that communication is oral. ${ }^{33}$ This is not particularly advantageous to the debtor because he can hardly be expected to assimilate the details of the validation notice through an oral encounter with the collector.

Although a debt collector can provide the necessary information in the initial communication, it is really an option that does not take a debtor's situation into account. A debtor is rarely in a frame of mind to receive an oral communication of this sort, particularly if he is unfamiliar with the collector's claim. ${ }^{34}$ It is understandable that Congress wanted to ensure that a collector would disclose the salient aspects of the transaction, but in doing so it lost sight of the fact that the "written notice" that must follow within five days does not require that the initial communication itself be written. ${ }^{35}$ The validation notice can be truly effective only if the collector is required to provide it in writing, regardless of the time of disclosure.

\section{B. Legal Pleadings}

Although the term "communication" is normally associated with the contact between a debt collector and a debtor, legal pleadings present their own challenges. There is some question about treating a summons and complaint as a communication, because they confuse the consumer with details that may conflict with the information in the validation

31. 15 U.S.C. $\$ 1692 \mathrm{~g}$.

32. "Communication" is the "conveying of information ... through any medium." 15 U.S.C. $\S$ $1692 \mathrm{a}(2)$.

33. The FTC Staff Commentary provides some support for oral notice by stating that "[i]f a debt collector's first communication with the consumer is oral, he may make the disclosures orally at that time in which case he need not send a written notice." FTC Staff Commentary, supra note 11, at 50,108. But see NAT'L CONSUMER LAW CTR., FAIR DEBT COLLECTION § 5.7.2.4, at 215-16 (5th ed. 2004) (exploring the legislative history of $\S 1692 \mathrm{~g}$ and suggesting that any ambiguity should be resolved in favor of written notice).

34. The Senate Report explained the validation notice as follows: "After initially contacting a consumer, a debt collector must send him or her written notice stating the name of the creditor and the amount owed." S. Rep. No. 95-382, at 4 (1977), reprinted in 1977 U.S.C.C.A.N. 1695, 1699.

35. The definition of "communication" contributes to the confusion. See 15 U.S.C. § 1692a(2) (defining "communication"). The drafters must have lost sight of the relationship between the "communication" and the details required to be disclosed by the collector. 
notice. ${ }^{36}$ This is particularly alarming if the debt collector includes that notice with the summons and complaint, each carrying its own period for the consumer to act. ${ }^{37}$ It is also arguable that a consumer can halt a lawsuit by seeking verification of the debt, even after the collector serves its summons and complaint. ${ }^{38}$ Furthermore, a consumer may be able to frustrate service of those documents by retaining counsel and asking the debt collector to deal with his lawyer only. ${ }^{39}$

Nevertheless, the FDCPA's definition of "communication" is broad and does not contain any exceptions. ${ }^{40}$ It is difficult, therefore, to ignore the statute's plain language in order to accommodate some administrative peculiarities. There is no evidence that a literal interpretation of the statute will lead to some absurd result that countermands congressional intent. ${ }^{41}$ After all, the whole objective of the statute is to protect consumers from unfair and deceptive collection practices, ${ }^{42}$ and if a legal pleading does not fall within the category of an "initial communication," then a debt collector can simply proceed to litigation without any obligation to provide the statutory validation notice. This possibility runs counter to the statutory scheme that provides a mechanism for a consumer to challenge the debt collector's

36. The court in Thomas v. Law Firm of Simpson \& Cybak alluded to some of the problems: While the $\S 1692 \mathrm{~g}$ notice indicates that the debtor has 30 days to dispute his debt, in federal court a defendant must answer a complaint within 20 days of its filing . . . Thus, the validation notice could potentially give a debtor the false impression that it has 30 days before it is required to take any action in the lawsuit.

392 F.3d 914, 919 (7th Cir. 2004).

37. For example, in a federal action, a defendant must answer a complaint within twenty days. FED. R. CIV. P. 12(a)(1)(A). On the other hand, a consumer has thirty days to dispute the debt. 15 U.S.C. $\S 1692 \mathrm{~g}(\mathrm{a})(4)(2000)$.

38. This was one of the collector's concerns in Thomas. 392 F.3d at 919.

39. See id. at 920 (recognizing that "[i]f pleadings are 'communications' under the FDCPA, in any jurisdiction in which a defendant must be personally served, a debtor could arguably thwart service by simply retaining an attorney.").

40. Communication is "the conveying of information regarding a debt directly or indirectly to any person through any medium." 15 U.S.C. $\S 1692 \mathrm{a}(2)$.

41. The Seventh Circuit said it best in Jenkins v. Heintz: "We must faithfully apply the law as Congress drafted it. We should not disregard plain statutory language in order to impose on the statute what we may consider a more reasonable meaning." 25 F.3d 536, 539 (7th Cir. 1994), aff'd, 514 U.S. 291 (1995); see also 2A NORMAn J. SingER, STATUTES AND STATUTORY CONSTRUCTION $\S 46: 01$ (6th ed. 2000 \& Supp. 2006) (discussing the "plain meaning rule" of statutory interpretation).

42. The Senate Report states clearly that the FDCPA's purpose is "to protect consumers from a host of unfair, harassing, and deceptive debt collection practices without imposing unnecessary restrictions on ethical debt collectors." S. Rep. No. 95-382, at 1-2 (1977), reprinted in 1977 U.S.C.C.A.N. 1695, 1696. 
claim informally, without having to engage the collector immediately in a litigation context. ${ }^{43}$

Treating a legal pleading as an initial communication serves the interest of debt collectors and consumers alike. It leads inevitably to a validation notice that informs the consumer of the right to dispute the debt. ${ }^{44}$ If the consumer exercises that right, the debt collector is then put on notice that something may be amiss, and thus is forced to delve into the validity of the claim. The consumer can express doubts about his alleged liability, and the debt collector can reassure itself about the transaction without expending too much energy and resources. ${ }^{45}$ The attempt to exclude legal pleadings from treatment as an initial communication is really only a continuation of previous attempts to carve out a special place for litigation activities. When a collector tried it in Heintz v. Jenkins, ${ }^{46}$ the Supreme Court of the United States let it be known that the FDCPA applies to lawyers who regularly attempt to collect debts through litigation. ${ }^{47}$ Despite such coverage, the Court was confident that the statute does not give a consumer the right to stop a collector's litigation activities under $\S 1692 \mathrm{c}(\mathrm{c})$, for the statute has exceptions that allow a debt collector to inform the consumer that it intends to invoke a certain remedy. ${ }^{48}$ If the collector can disclose its intent about the remedy, it can surely invoke the actual remedy. ${ }^{49}$ The Court, therefore, did not read that language as preventing the FDCPA from covering an attorney-collector because such language was consistent with the preservation of the collector's judicial remedies. ${ }^{50}$

43. The validation section is intended to "eliminate the recurring problem of debt collectors dunning the wrong person or attempting to collect debts which the consumer has already paid." Id. at 4, reprinted in 1977 U.S.C.C.A.N. at 1699.

44. The debt collector must include the validation notice in the initial communication or within five days thereafter. 15 U.S.C. $\S 1692 \mathrm{~g}(\mathrm{a})(2000)$.

45. It has been said that the validation section provides "an informal method of dispute resolution that conserves tax dollars and judicial resources." NAT'L CONSUMER LAW CTR., supra note $33, \S 5.7 .1$, at 212. Congress regarded the section as a "significant feature of [the] legislation." S. Rep. No. 95-382, at 4, reprinted in 1977 U.S.C.C.A.N. at 1699. The Senate Report confirmed that the provision would not cause any additional expense or paperwork because most collectors send similar information to consumers. Id.

46. 514 U.S. 291 (1995).

47. Id. at 294.

48. Id. at 296 .

49. See id. (explaining that the exceptions can be read "to imply that they authorize the actual invocation of the remedy that the collector "intends to invoke"').

50. See id. at 294 ("In ordinary English, a lawyer who regularly tries to obtain payment of consumer debts through legal proceedings is a lawyer who regularly 'attempts' to 'collect' those consumer debts.”) (emphasis added) (citing BLACK’s LAW DiCTIONARY 263 (6th ed. 1990)). 
When the Seventh Circuit had a second try at the issue in Thomas $v$. Law Firm of Simpson \& Cybak, ${ }^{51}$ it confirmed that a summons and complaint constituted a communication under the FDCPA and it allayed collectors' fears that this decision would empower a consumer to stop the litigating collector in its tracks. ${ }^{52}$ Although it is true that a consumer can seek verification of a debt within thirty days after receiving a validation notice, a debt collector can avoid that difficulty by having its initial communication with the consumer and then waiting thirty days to serve its pleadings. ${ }^{53}$ This strategy would still allow the consumer the opportunity to exercise his validation rights, while making way for the debt collector to begin litigation without fear of interruption. ${ }^{54}$

There is another advantage to separating an initial communication from the service of the legal pleadings. It would insulate the debt collector from the charge that it has confused the consumer with different documents having varying deadlines. ${ }^{55}$ The FDCPA gives the consumer thirty days to dispute a debt, but court rules may prescribe other limits for the consumer's response in the litigation context. ${ }^{56}$ This is the classic

51. 392 F.3d 914, 918 (7th Cir. 2004)

52. See id. (citing the Supreme Court's rejection in Heintz of the collector's arguments that subjecting lawyers to the FDCPA would create insuperable difficulties for the litigation process).

53. Id. at 919; see also En Banc Seventh Circuit: Collector's Summons and Complaint Triggered Consumer's FDCPA Debt Validation Rights, 23 NCLC REPORTS: DEBT COLLECTION AND REPOSSESSIONS EDITION 11-12 (Nov./Dec. 2004) (citing the court's recommendation to send debt validation notices thirty days before suit); How May Plaintiff's Lawyer Comply with the Fair Debt Collection Practices Act, 36 CONSUMER CREDIT \& TRUTH-IN-LENDING COMPLiANCE REPORT 3 (Earl Phillips ed. Mar. 2005) ("'Initially communicating' with the consumer more than 30 days before ... avoids other complications.").

54. The Thomas court provided some guidance on the kind of language that a collector should use in the validation notice if the collector felt it necessary because of other concerns to include the notice with the summons and complaint or within five days thereafter. See 392 F.3d at 919 (explaining that if the debt collector does not notify the debtor of his rights in the initial communication, the debt collector "should take care to phrase its notice so as to not mislead"). The court's safe-harbor language was as follows:

This advice pertains to your dealings with me as a debt collector. It does not affect your dealings with the court, and in particular it does not change the time at which you must answer the complaint. The summons is a command from the court, not from me, and you must follow its instructions even if you dispute the validity or amount of the debt. The advice in this letter also does not affect my relations with the court. As a lawyer, I may

file papers in the suit according to the court's rules and the judge's instructions.

Id. at 919-20.

55. See id. (explaining the confusion that can arise when the debtor has twenty days to answer the complaint, but thirty days to dispute a debt in federal court).

56. See id. at 919 ("A debtor must comply with deadlines imposed by court rules and judges, even if that debtor has requested verification of the debt.") State rules may also prevent a collector from including a validation notice in court documents. In that event, the best approach is for the collector to provide the validation notice to the consumer before serving the court papers or within five days thereafter. See Advisory Opinion, supra note 23 (demonstrating that regardless of where the consumer lives - in a jurisdiction that prohibits including validation notices with court 
scenario for a claim that the litigation documents contradict or overshadow the validation notice. ${ }^{57}$ A consumer could be confused by the statutory deadlines. ${ }^{58}$ This is not to say that a debt collector is helpless in the face of these requirements. If a debt collector wants to start litigation within the thirty-day period and run the risk that the consumer will seek verification of the debt during that time, it must take every precaution to explain in its communication how the validation notice and the legal pleadings fit together, so that it does not mislead the consumer into forfeiting his rights under either procedure. ${ }^{59}$ There is nothing unusual about this approach, for the Seventh Circuit rose to the occasion in another context by providing a model collection letter for the guidance of debt collectors when there was potential for confusion, and the court wanted to show how a debt collector could assert its claim while simultaneously preserving the consumer's right to dispute the debt. $^{60}$

When a collector knows that a consumer has retained a lawyer, the FDCPA prevents the debt collector from communicating with the consumer. ${ }^{61}$ A consumer can create problems for a debt collector in a jurisdiction where a person must be personally served with court documents for litigation to proceed. In that event, the debt collector should be able to communicate, with a court's permission, in the form of

documents or one that permits this practice - the consumer will receive the notice).

57. In Law Offices of David J. Stern, P.A. v. Martinez (In re Martinez), 271 B.R. 696, 699 (S.D. Fla. 2001), aff'd, 311 F.3d 1272 (11th Cir. 2002), the validation notice appeared as page eight of a sixteen-page foreclosure document. The court found that "the hypothetical least sophisticated consume[r] would likely respond to the foreclosure complaint within the prescribed thirty days, ignoring his FDCPA rights, as the language in the summonses and foreclosure complaint overshadows the message required to be effectively conveyed by the FDCPA Notice." Id. at 701. The collector made no attempt to reconcile or explain the conflicting requirements of the validation notice and of the legal pleadings. Id. Courts have frequently found a validation notice to be ineffective if it is accompanied by other language that renders the communication contradictory or overshadowing. E.g., Bartlett v. Heibl, 128 F.3d 497, 500 (7th Cir. 1997); Clomon v. Jackson, 988 F.2d 1314, 1319 (2d Cir. 1993); Graziano v. Harrison, 950 F.2d 107, 111 (3d Cir. 1991).

58. Thomas, 392 F.3d at 919 . There is a potential for confusion because although the validation notice gives a debtor thirty days to dispute a debt, the federal rules require a defendant to answer a complaint within twenty days. Compare 15 U.S.C. $\S 1692 \mathrm{~g}$ (2000) (giving a debtor thirty days to challenge the validity of a debt), with FED. R. CIV. P. 12(a)(1)(A) (giving a defendant only twenty days to respond to a complaint).

59. The Thomas court provided some safe-harbor language that responded to these concerns. 392 F.3d at 919-20. This was not the first time that the Seventh Circuit found itself in the position of providing some guidance on appropriate language. See Miller v. McCalla, Raymer, Padrick, Cobb, Nichols, \& Clark, L.L.C., 214 F.3d 872, 876 (7th Cir. 2000) (suggesting language that would satisfy disclosure of the amount of the debt under $\S 1692 \mathrm{~g}(\mathrm{a})(1))$; Bartlett, $128 \mathrm{~F} .3 \mathrm{~d}$ at 501-02 (suggesting a safe-harbor letter that would avoid a violation by reconciling the validation notice with the collector's right to collect the debt).

60. See Bartlett, 128 F.3d at 501-02 (providing the court's model collection letter).

61. 15 U.S.C. $\S 1692 \mathrm{c}(\mathrm{a})(2)(2000)$. 
legal pleadings with the represented consumer so as to solve this potential problem. ${ }^{62}$ This mechanism allows the debt collector to achieve its objective without violating the statutory prohibition against contacting the consumer against his will. Congress did not intend to suppress a debt collector's right to begin the litigation process by merely allowing a consumer to demand that the debt collector cease communicating. ${ }^{63}$ Thus, even in the face of these administrative challenges, it is not reasonable to ignore the plain language of the statute by treating legal pleadings as if they are not a communication.

It is noteworthy that the FDCPA does address legal actions by debt collectors, and some have argued that since $\S 1692 \mathrm{i}$ merely regulates venue issues, Congress did not intend to cover abuses dealing with legal pleadings. ${ }^{64}$ But if Congress had already decided that legal pleadings fell within the definition of "communication," it would have been unnecessary to complicate matters by including language in $\S 1692 \mathrm{i}$ that had nothing to do with venue. Furthermore, when the drafters wanted to ensure that a particular provision would not cover a legal pleading, they knew how to do so by creating a specific exemption for it. ${ }^{65}$ Thus, a debt

62. The Thomas court observed that exceptions in $\S 1692 \mathrm{c}$ could be interpreted as allowing personal service on a represented consumer: "For instance, $\S 1692 \mathrm{c}(\mathrm{a})$ permits communication with debtors represented by attorneys with the express permission of the court. Court rules permitting service could be interpreted as granting such express permission." 392 F.3d at 920; see also En banc Seventh Circuit, supra note 53, at 12 (concluding the law allows debt collectors to serve a summons and complaint on a debtor represented by an attorney); How May Plaintiff's Lawyer Comply with the Fair Debt Collection Practices Act, supra note 53, at 4 (same).

63. The petitioners in Heintz v. Jenkins, 514 U.S. 291, 296 (1995), had raised similar questions about the difficulties that lawyers would face if the Court subjected the lawyer's litigation activities to the FDCPA. The Court responded in this way:

We agree with Heintz that it would be odd if the Act empowered a debt owing consumer to stop the "communications" inherent in an ordinary lawsuit and thereby cause an ordinary debt-collecting lawsuit to grind to a halt. But, it is not necessary to read $\S$ $1692 \mathrm{c}(\mathrm{c})$ in that way-if only because that provision has exceptions that permit communications "to notify the consumer that the debt collector or creditor may invoke" or "intends to invoke" a "specified remedy" (of a kind "ordinarily invoked by [the] debt collector or creditor"). $\S \S 1692$ c(c)(2), (3). Courts can read these exceptions, plausibly, to imply that they authorize the actual invocation of the remedy that the collector "intends to invoke." The language permits such a reading, for an ordinary court-related document Id. does, in fact, "notify" its recipient that the creditor may "invoke" a judicial remedy.

64. See McKnight v. Benitez, 176 F. Supp. 2d 1301, 1305 (M.D. Fla. 2001) (referring to 15 U.S.C. $\S 1692 \mathrm{i}$ (2000), which deals with legal actions by debt collectors). The court suggested that Congress would have included in $\S 1692 \mathrm{i}$ anything that related to legal remedies, including the filing of a legal pleading. Id.

65. Section 1692e exempts "a formal pleading made in connection with a legal action." 15 U.S.C. $\S 1692 \mathrm{e}(11)$ (2000). So a debt collector does not have to indicate in such a pleading that it is attempting to collect a debt and that any information obtained will be used for that purpose. Neither does it have to state that the communication is from a debt collector. Id. 
collector does not have to state in a formal pleading that such communication is from a debt collector, although a debt collector must include such a statement in all other communications after the first. ${ }^{66}$ This $\S 1692 \mathrm{e}(11)$ exception leaves no doubt that Congress intended to exclude legal pleadings from the communications that must contain the appropriate statutory language. If Congress did not regard such a legal pleading as a communication, it would have been unnecessary to draft this specific language to exclude a legal pleading from $\S 1692 \mathrm{e}(11){ }^{67}$

The Eleventh Circuit came to a different conclusion in Vega $v$. McKay ${ }^{68}$ but it relied on the Federal Trade Commission (FTC) Staff Commentary which took the position that a legal pleading was not a communication. $^{69}$ Now that a subsequent FTC Advisory Opinion has stated that it is a communication, ${ }^{70}$ the Eleventh Circuit has lost the support for its decision. In all fairness, one must remember that the Commentary on which the Eleventh Circuit relied preceded the Heintz decision, and thus the FTC did not have the advantage of the Court's view that lawyers were not exempt from the FDCPA. ${ }^{71}$ Now that the FTC has made its position clear, the Eleventh Circuit will have to seek a basis elsewhere to support its position. It is doubtful that it can make a compelling case in light of the Seventh Circuit's approach in Thomas. The essential inquiry remains whether Congress would have wanted to exclude a legal pleading from the definition of "communication" if that would allow a debt collector to avoid its validation obligation. ${ }^{72}$ It seems

66. Id.; see also NAT'L CONSUMER LAW CTR., supra note 33, § 5.5.14.1, at 191-92.

67. See Goldman v. Cohen, 446 F.3d 152, 156 (2d Cir. 2006) (the term "communication" includes legal pleadings); Nichols v. Byrd, 435 F. Supp. 2d 1101, 1106 (D. Nev. 2006) (same); Alger v. Ganick, O’Brien \& Sarin, 35 F. Supp. 2d 148, 158 n.18 (D. Mass. 1999) (same); Gunter v. Columbus Check Cashiers, Inc. (In re Gunter), 334 B.R. 900, 905-06 (Bankr. S. D. Ohio 2005) (same).

68. 351 F.3d 1334 (2003).

69. The court in Vega v. McKay explained as follows: "In making this decision we give serious consideration to the interpretation put forth by the Federal Trade Commission which is the agency changed [sic] with enforcing the provisions of the FDCPA and has developed the expertise in this area." Id. at 1337. The court agreed with McKnight v. Benitez, 176 F. Supp. 2d 1301, 1308 (M.D. Fla. 2001), which had also relied on the FTC Staff Commentary. Vega, 351 F.3d at 1336-37.

70. See Advisory Opinion, supra note 23 (stating that "if an attorney debt collector serves on a consumer a court document 'conveying [] information regarding a debt,' that court document is a 'communication' for the purposes of the FDCPA").

71. The FTC Staff issued the Commentary in 1988, and the Supreme Court decided Heintz v. Jenkins in 1995. See supra notes 11, 14

72. In Thomas v. Law Firm of Simpson \& Cybak, the Seventh Circuit explained the loophole that would result from not treating a legal pleading as a communication:

Such a loophole, creating an end-run around the validation notice requirement, is inconsistent with the drafters' intention of protecting debtors from "unfair, harassing, and deceptive" collection tactics, especially because many debtors cannot afford to hire attorneys to represent them in collection actions. Congress was careful to except 
unlikely, given Congress's careful crafting of an exception in $\S$ $1692 \mathrm{e}(11)$.

\section{Other Legal Actions}

Communication can come in many forms. A legal pleading is not the only mechanism that has raised questions. Similar queries were raised in Romea $v$. Heiberger \& Associates, ${ }^{73}$ when the defendant sent a three-day rent demand notice to the consumer that was required before beginning a summary eviction proceeding. ${ }^{74}$ Despite the defendant's contention that the summary eviction proceeding concerned the "rights of possession of real property," 75 the Second Circuit held that the letter the defendant sent to the consumer was a communication because it conveyed information regarding a debt. ${ }^{76}$ Although the notice that the defendant sent was a condition precedent to the institution of the eviction proceeding, an action in rem, the defendant intended the letter to be an inducement to the consumer to pay the debt. ${ }^{77}$ The notice demanding payment was not a part of the eviction proceeding, but rather a precursor to it, and it informed the consumer about what he must do if he hoped to avoid that proceeding. ${ }^{78}$ In using the notice to obtain payment, the defendant was open to the same temptations that plague the collection process, and the fact that the debtor's delinquency might lead to summary eviction did not change the nature of the notice required by the statute under consideration in Romea ${ }^{79}$

pleadings from the definition of "communication" where it so intended.

392 F.3d 914, 918 (7th Cir. 2004).

73. 163 F.3d 111, 114 (2d Cir. 1998).

74. Id. at 113

75. Id. at 116. The purpose of an Article 7 proceeding under New York Law is to provide a procedure "to recover real property." N.Y. REAL PROP. ACTS. LAW § 701 (McKinney 1979); see also Tivoli Assocs. v. Wing, 471 N.Y.S.2d 1018, 1019 (N.Y. Civ. Ct. 1984) (referring to Article 7's subject matter as "the right of possession of real property").

76. Romea, 163 F.3d at 116.

77. Id.

78. Id. at 113; see also Paulemon v. Tobin, 30 F.3d 307, 310 (2d Cir. 1994) (holding that letters sent to a debtor do not qualify under a litigation exemption to the FDCPA, if one exists); J.D. Realty Assocs. v. Jorrin, 632 N.Y.S.2d 441, 444 (N.Y. Civ. Ct. 1995) (referring to the three-day notice as "a notice to the tenant of what must be done to forestall a summary proceeding"), aff'd sub nom. J.D. Realty Assocs. v. Scoullar, 650 N.Y.S. 2d 67, 68 (N.Y. App. Term 1996).

79. Under New York law, a landlord may bring an Article 7 proceeding to recover possession from a tenant if the tenant has defaulted on rent and if "a demand of the rent has been made, or at least three days' notice in writing requiring, in the alternative, the payment of the rent, or the possession of the premises, has been served upon him." N.Y. REAL PROP. ACTS. LAW § 711(2) (McKinney 1979). The summary proceeding to recover possession cannot begin unless the landlord has served his statutory notice. Romea, 163 F.3d at 116 . In Romea, such a notice was a "communication" because it conveyed information about the debt, even though the legal proceeding 
When a communication occurs within the context of enforcing a lien, the FDCPA should still apply once a debt collector is trying to collect a debt. In Piper v. Portnoff Law Associates, Ltd., ${ }^{80}$ the defendant argued for exemption from the FDCPA because it was merely trying to enforce a lien for the consumer's water bills. ${ }^{81}$ The only problem was that the defendant had already sent out several collection letters that demanded payment and had advised the consumers that their failure to pay could result in a sheriff's sale of their property. ${ }^{82}$ Only after the consumers failed to pay was a lien placed on their property. ${ }^{83}$ The defendant believed that its decision to execute on the lien, rather than seek a personal judgment against the consumers, took the transaction out of the scope of the FDCPA. ${ }^{84}$

There was no doubt that the defendant's communications with the consumers were in connection with the collection of a debt, for every letter the defendant sent to the consumers requested payment of the water bills. ${ }^{85}$ The defendant had even accepted partial payment in satisfaction of the outstanding debt, and its sole business was to collect similar claims. By throwing a lien into the mix, the defendant had hoped to convince the court that it was not really a debt collector, because it was only enforcing a lien, rather than collecting a debt. It is true that a person whose principal business is the enforcement of security interests is

had not yet commenced. Id; see also Kara B. Schissler, Note, Come and Knock on Our Door: The Fair Debt Collection Practices Act's Intrusion Into New York's Summary Proceedings Law, 22 CARDOZO L. REV. 315, 331-33 (2001) (summarizing the details of Romea).

80. 396 F.3d 227 (3d Cir. 2005)

81. Id. at 234 .

82. Id. at $229-30$.

83. Id. at 230 .

84. Id. at $231-32$.

85. Id. at 233. The defendant's testimony gave some idea of what the defendant was trying to accomplish:

Q. Let me pick up on that. You are not looking for payments from the real estate but payments from these individuals, is that correct?

A. That is correct. It is my-the record owners of the real estate would pay their delinquent tax and water bills.

Q. If they tendered personal checks, are they accepted?

A. Yes.

$$
\text { .... }
$$

Q. Your hope is to get the persons, the individuals to pay the money?

A. Right. Our hope is that they pay as soon as possible in fact.

Q. You are not looking to liquidate the real property, but the payment from the individuals?

A. That is correct.

Id. The mere fact that the letters to the consumer preceded the enforcement of a lien did not change the nature of the "communication." Id. at 233-34; see also Pollice v. Nat'l Tax Funding, L.P., 225 F.3d 379, 401 (3d Cir. 2000). 
treated as a debt collector only for purposes of $\S 1692 \mathrm{f}(6),{ }^{86}$ but in Piper, the defendant was engaged in other activity that qualified it as a collector, and it could not, therefore, be forgiven for not complying with other sections of the FDCPA. ${ }^{87}$

Similar ambiguities arise in real estate transactions. When a trustee forecloses on a trust deed, he does not bring himself within the FDCPA. ${ }^{88}$ The FDCPA is intended to curb abusive and deceptive collection practices when a collector tries to recover funds from a debtor. In such a foreclosure, a lender is merely trying to foreclose its interest in the property. ${ }^{89}$ When a trustee exercises his power of sale under a trust deed, he is not enforcing the obligation against the consumer personally. ${ }^{90}$ Therefore, the foreclosure of the property is not the collection of a debt within the meaning of the statute. ${ }^{91}$ However, when the proceeding is not a foreclosure pursuant to a trust deed, but is instead a judicial foreclosure under a mortgage, the FDCPA does apply. ${ }^{92}$ In the latter case, the collector usually seeks judgment on the note, and thus it is different from the nonjudicial sale where the trustee's interest is in pursuing the property, from which he hopes to satisfy the debt.

Even when a deed of trust is involved, it is possible that a trustee's conduct may subject the transaction to the FDCPA. There was a recent

86. Section $1692 \mathrm{a}(6)$ provides that "[f]or the purpose of section $1692 \mathrm{f}(6)$. . . such term [debt collector] also includes any person who uses any instrumentality of interstate commerce or the mails in any business the principal purpose of which is the enforcement of security interests." 15 U.S.C. $\S$ 1692a(6) (2000). Section 1692f(6) then makes it an unfair practice for such a debt collector to take nonjudicial action to repossess property under certain circumstances. 15 U.S.C. § $1692 \mathrm{f}(6)$ (2000).

87. Piper, 396 F.3d at 236. Section 1692a(6) recognizes the specialty of the repossession agency, which does not extend to the daily communication with debtors in order to recover a debt. Id. Such agencies are not subject to the FDCPA except for $\S 1692 \mathrm{f}(6)$. See, e.g., Goldstein v. Chrysler Fin. Co., 276 F. Supp. 2d 687, 690 (E.D. Mich. 2003) (holding that "skip tracing firm" was not a "debt collector"); Seibel v. Soc'y Lease, Inc., 969 F. Supp. 713, 716 (M.D. Fla. 1997) (holding that a respossession agency is not a "debt collector" except for the purpose of $\S 1692 \mathrm{f}(6))$ ); Jordan v. Kent Recovery Servs., 731 F. Supp. 652, 659 (D. Del. 1990) (same).

88. See Bergs v. Hoover, Bax \& Slovacek, L.L.P., No. 3:01-CV-1572-L, 2003 WL 22255679, at *6 (N.D. Tex. Sept. 24, 2003) (foreclosure not debt collection under FDCPA); Hulse v. Ocwen Fed. Bank, FSB, 195 F. Supp. 2d 1188, 1204 (D. Or. 2002) (same); Heinemann v. Jim Walter Homes, Inc., 47 F. Supp. 2d 716, 722 (N.D. W. Va. 1998) (same), aff'd, 173 F.3d 850 (4th Cir. 1999).

89. Hulse, 195 F. Supp. $2 \mathrm{~d}$ at 1204.

90. See Beadle v. Haughey, No. 04-272-SM, 2005 WL 300060, at*3 (D.N.H. Feb. 9, 2005) (distinguishing McDaniel v. South \& Assocs., P.C., 325 F. Supp. 2d 1210, 1217-18 (D. Kan. 2004)).

91. Hulse, 195 F. Supp. 2d at 1204; Heinemann, 47 F. Supp. 2d at 722.

92. McDaniel, 325 F. Supp. 2d at 1217-18. But cf. Rosado v. Taylor, 324 F. Supp. 2d 917, 926 (N.D. Ind. 2004) (holding the FDCPA did not apply to the summons and complaint seeking judical foreclosure, but did apply to the "FDCPA notice" sent to the debtor with the summons and complaint). See generally NAT'L CONSUMER LAW CTR., supra note 33, § 4.2.5 (discussing FDCPA applicability to foreclosure companies). 
example of this in Wilson v. Draper \& Goldberg, P.L.L.C., ${ }^{93}$ when the Fourth Circuit decided that the trustee's activities under a deed of trust fell within the statute despite the commencement of foreclosure proceedings. $^{94}$

It was understandable that the court in Wilson did not exempt this transaction from the statute since the defendants not only notified the consumer about a default in payment, but also indicated that they were doing so pursuant to the FDCPA. ${ }^{95}$ The defendants then proceeded to include the usual validation notice which gave specific information about the debt, while advising the consumer about the opportunity to dispute the debt. ${ }^{96}$ But the notice did not end there, for the defendants assured the consumer that they were attempting to collect a debt, ${ }^{97}$ while at the same time denying that they were debt collectors. ${ }^{98}$

The defendants were obviously trying to straddle the fence by nudging the consumer into paying, instead of merely enforcing the security interest. If there was any doubt about the defendants' strategy, it was dispelled by the defendants' last letter to the consumer that gave the amount required to reinstate the account and directed the consumer to send in a cashier's check payable to the lender for the amount due. ${ }^{99}$ Despite their denial, the defendants gave every indication that they were trying to collect a debt, as evidenced by the inclusion of a validation notice in their communication with the consumer and their own admission of their collection activity. ${ }^{100}$

The message inherent in the Wilson decision is that the enforcement of a lien or a foreclosure under a deed of trust does not convert a true debt collector into a mere enforcer of a security interest. ${ }^{101}$ One must

\footnotetext{
93. 443 F.3d 373 (4th Cir. 2006).

94. Id. at 376 .

95. Id. at 374 .

96. Id. at 375 . The validation notice gives the consumer basic information about the debt and explains what the debt collector must do if the consumer disputes the debt within thirty days after receiving the debt collector's notice. 15 U.S.C. $§ 1692 \mathrm{~g}(\mathrm{a})(2000)$.

97. Wilson, 443 F.3d at 374.

98. Id. at 375 .

99. Id. This letter also indicated that the defendants were attempting to collect a debt. The defendant must have been motivated by the statutory requirement that the collector should indicate in its initial communication that it is trying to collect a debt. See 15 U.S.C. § 1692e(11) (2000) (describing statutory requirements). However, this was not the initial communication.

100. Wilson, 443 F.3d at 374-75.

101. A person whose principal business is the enforcement of a security interest is a debt collector only for purposes of $\S 1692 \mathrm{f}(6)$ of the FDCPA. 15 U.S.C. $\S 1692 \mathrm{a}(6)$ (2000). But if that person regularly collects debts for someone else, that person is subject to all provisions of the FDCPA and cannot escape coverage simply because he is also engaged in foreclosures. Id. The $\S$ $1692 \mathrm{f}(6)$ restriction applies only to those "whose only role in the debt collection process is the
} 
look at the whole picture to make a determination. ${ }^{102}$ Cases like Wilson simply underscore the fact that a trustee's ability to recover a debt, or any part thereof, through a nonjudical sale, in no way restricts the trustee in pursuing the consumer with presale demands. ${ }^{103}$ It is this combination that poses problems for a trustee under a deed of trust because, as Wilson suggests, a trustee cannot engage in traditional collection activity and then seek refuge in a nonjudicial sale. ${ }^{104}$

\section{FALSE, DECEPTIVE, OR MISLEADING REPRESENTATIONS}

"A debt collector may not use any false, deceptive, or misleading representation" to collect a debt. ${ }^{105}$ Although $\S 1692 \mathrm{e}$ uses this general standard to control a debt collector's activities, the statute also includes, without limitation, sixteen categories of prohibited conduct. ${ }^{106}$ The FDCPA builds on the concept of deception developed in the FTC Act, ${ }^{107}$ and the courts continue to support the proposition that it is sufficient to show that a debt collector's conduct has a tendency to deceive and that actual deception is not necessary to show a violation. ${ }^{108}$ This approach

enforcement of a security interest." Wilson, 443 F.3d at 378 (citing Jordan v. Kent Recovery Servs., Inc., 731 F. Supp. 652, 657 (D. Del. 1990)); see also Montgomery v. Huntington Bank, 346 F.3d 693, 699 (6th Cir. 2003) (enforcer of security interest does not meet definition of debt collector, except for purposes of $\S 1692 \mathrm{f}(6))$; Rosado v. Taylor, 324 F. Supp. 2d 917, 924 (N.D. Ind. 2004) (“[E]nforcing a security interest is not debt collection.”); Seibel v. Soc'y Lease, Inc., 969 F. Supp. 713, 717 (M.D. Fla. 1997) (repossession agency falls within FDCPA only when it is enforcing a security interest).

102. Compare Fong v. Prof'l Foreclosure Corp., No. CO5-448JLR, 2005 WL 3134059, at *2 (W.D. Wash. Nov. 22, 2005) (trustee pursuing foreclosure under a deed of trust is not debt collector), and Gonzalez v. Nw. Tr. Servs., Inc., No. Civ. 05-6081-AA, 2005 WL 2297097, at*1 (D. Or. Sept. 20, 2005) (same), and Hulse v. Ocwen Fed. Bank, FSB, 195 F. Supp. 2d 1188, 1211 (D. Or. 2002) (same), with Wilson v. Draper \& Goldberg, P.L.L.C., 443 F.3d 373, 376 (4th Cir. 2006) (trustee's conduct related to the collection of debt), and Piper v. Portnoff Assocs., 396 F.3d 227, 234 (3d Cir. 2005) (law firm was debt collector even though debt was secured by lien), and Shapiro \& Meinhold v. Zartman, 823 P.2d 120, 124 (Colo. 1992) (attorneys not exempt from FDCPA simply because their collection activities were primarily limited to foreclosures).

103. 443 F.3d at $374-75$.

104. The court recognized that the "Defendants' October 15 letter to Wilson contained a specific request for money to 'reinstate the above account' even after the foreclosure proceedings began." Id. at 375. The court construed this language as an attempt to collect a debt. Id.; see also Fourth Circuit Holds FDCPA Applies to Foreclosure Law Firm, 24 NCLC REPORTS: DEBT COLLECTION AND REPOSSESSIONS EDITION 22 (May/June 2006) (discussing this interpretation).

105. 15 U.S.C. $\S 1692$ e (2000).

106. Section 1692e lists sixteen categories of false, deceptive, or misleading representations "[w]ithout limiting the general application" of the statute to prohibited conduct. Id.

107. 15 U.S.C. $\S 45$ (2000). The FTC Act declares "[u]nfair methods of competition in or affecting commerce, and unfair or deceptive acts or practices in or affecting commerce . . . [to be] unlawful." Id. § 45(a)(1).

108. See, e.g., United States v. Nat'l Fin. Servs., Inc., 98 F.3d 131, 139 (4th Cir. 1996) ("[T]he test is the capacity of the statement to mislead; evidence of actual deception is unnecessary."); Jeter 
lends credibility to the notion that a debt collector may still be liable if it employs a literally true statement that turns out to be deceptive because of a misleading implication. ${ }^{109}$ It is conceivable, therefore, for a debt collector to violate the statute if it fails to make affirmative disclosures which are necessary "to avoid the deceptive implication of a statement." 110 In construing $\S 1692 \mathrm{e}$, the courts take a liberal approach by applying an objective standard of deception to the "least sophisticated" 111 or the "unsophisticated" consumer. ${ }^{112}$ Therefore, a

v. Credit Bureau, Inc., 760 F.2d 1168, 1175 (11th Cir. 1985) (discussing the "tendency to mislead" standard of deception); see also Kevin W. Brown, Annotation, What Constitutes False, Deceptive, or Misleading Representation or Means in Connection With Collection of Debt Proscribed by Provisions of Fair Debt Collection Practices Act (15 USCS \& 1692e), 67 A.L.R. FED. 974 (1984 \& Supp. 2005) (discussing the tests courts use to "measure whether particular conduct is deceptive or misleading").

109. See Avila v. Rubin, 84 F.3d 222, 227 (7th Cir. 1996) (finding that a letter containing technically true but misleading statements violated the FDCPA); Gammon v. GC Servs. Ltd. P'ship, 27 F.3d 1254, 1258 (7th Cir. 1994) (same); Gradisher v. Check Enforcement Unit, Inc., 210 F. Supp. 2d 907, 917 n.3 (W.D. Mich. 2002) (same); Faust v. Texaco Ref. \& Mktg., Inc. (In re Faust), 270 B.R. 310, 319 (M.D. Ga. 1998) (same); Weiss v. Collection Ctr., Inc., 667 N.W.2d 567, 572 (N.D. 2003) (same).

110. NAT'L CONSUMER LAW CTR., supra note 33, § 5.5.2.5, at 150; see also Gammon, 27 F.3d at 1257 (holding that consumer might infer that debt collector was affiliated with government because collector had stated that it had provided the systems used in collecting taxes); Drennan v. Van Ru Credit Corp., 950 F. Supp. 858, 859 (N.D. Ill. 1996) (claim stated where defendant mentioned "legal review notification" and "notice of possible wage garnishment" but took no action for more than one year); Dutton v. Wolhar, 809 F. Supp. 1130, 1141 (D. Del. 1992) (holding that language "once judgment is obtained" falsely misrepresented debt collector's ability to get a judgment), aff'd sub nom. Dutton v. Wolpoff \& Abramson, 5 F.3d 649 (3d Cir. 1993).

111. See Lewis v. ACB Bus. Servs., 135 F.3d 389, 400 (6th Cir. 1998) (courts apply objective test based on understanding of the "least sophisticated consumer"); Bentley v. Great Lakes Collection Bureau, 6 F.3d 60, 63 (2d Cir. 1993) (same); Swanson v. S. Or. Credit Serv., Inc., 869 F.2d 1222, 1227 (9th Cir. 1988) (least sophisticated consumer test applies to threats of legal action); see also NAT'L CONSUMER LAW CTR., supra note 33, § 5.5.2.5, at 150 (discussing least sophisticated consumer test).

In Clomon v. Jackson, 988 F.2d 1314 (2d Cir. 1993), the court explained the purpose of the least sophisticated consumer test:

The basic purpose of the least sophisticated consumer standard is to ensure that the

FDCPA protects all consumers, the gullible as well as the shrewd.

$\cdots$

To serve the purposes of the consumer-protection laws, courts have attempted to articulate a standard for evaluating deceptiveness that does not rely on assumptions about the "average" or "normal" consumer. This effort is grounded, quite sensibly, in the assumption that consumers of below-average sophistication or intelligence are especially vulnerable to fraudulent schemes.

Id. at $1318-19$.

Most courts have applied the least sophisticated consumer standard to the FDCPA in other contexts. See Russell v. Equifax A.R.S., 74 F.3d 30, 34 (2d Cir. 1996) (using "least sophisticated consumer" standard to determine violation of $\S 1652 \mathrm{~g}$ ); Graziano v. Harrison, 950 F.2d 107, 111 (3d Cir. 1991) (same); Chaudhry v. Gallerizzo, 174 F.3d 394, 409 (4th Cir. 1999) (upholding application of "least sophisticated debtor" standard to $\S 1652 \mathrm{~g}$ action); Smith v. Transworld Sys., Inc., 953 F.2d 1025, 1028-29 (6th Cir. 1992) (same); Johnson v. Eaton, 873 F. Supp. 1019, 1022 (M.D. La. 1995) ("least sophisticated consumer or debtor standard" is used in determining violations of $\S 1652 \mathrm{~g}$ ), 
collector cannot be exonerated on the basis of the truth of its statement if that statement is subject to more than one interpretation, one of which has the capacity to deceive. ${ }^{113}$

\section{A. The Attorney's Role}

One way in which a debt collector may intimidate a consumer is by giving the impression that a communication has come from an attorney. ${ }^{114}$ That strategy is designed to strike fear in the heart of the consumer so that the consumer will respond promptly to the demand for payment. In Clomon v. Jackson, for example, a collection agency used an attorney's letterhead to send out letters with a facsimile signature of the attorney as general counsel of NCB Collection Services. ${ }^{115}$ The use of the letterhead and the signature was intended to give the impression

aff'd in part, rev'd in part, 80 F.3d 148 (5th Cir. 1996).

112. In Gammon, the court expressed some dissatisfaction with the "least sophisticated consumer" standard and opted instead for the "unsophisticated consumer" test. 27 F.3d at 1257. The court explained its preference this way:

[W]e will use the term, "unsophisticated," instead of the phrase, "least sophisticated," to describe the hypothetical consumer whose reasonable perceptions will be used to determine if collection messages are deceptive or misleading. We reiterate that an unsophisticated consumer standard protects the consumer who is uninformed, naive, or trusting, yet it admits an objective element of reasonableness. The reasonableness element in turn shields complying debt collectors from liability for unrealistic or peculiar interpretations of collection letters.

Id. A little later, the Seventh Circuit explained in Avila v. Rubin, 84 F.3d 222, 227 (7th Cir. 1996), that Gammon did not "significantly change the substance of the 'least sophisticated consumer' standard as it had been routinely applied by courts." The court concluded that "the unsophisticated consumer standard is a distinction without much of a practical difference in application." Id.; see also Peters v. Gen. Serv. Bureau, Inc., 277 F.3d 1051, 1055 (8th Cir. 2002) (stating that a violation of $\S 1692$ e must be "viewed through the eyes of an unsophisticated consumer").

113. See Nat'l Fin. Servs., 98 F.3d at 138 (finding that collector's mass mailings implied that attorney had reviewed files and decided that consumer would be subject to suit); Clomon, 988 F.2d at 1320-21 (holding that language in collection letter sufficient to create false impression that attorney had reviewed files); Gradisher, 210 F. Supp. 2d at 915-17 (holding that notice which stated "failure to Make Payment Can Result in a Warrant for Your Arrest" would lead a consumer to the false conclusion that he would be prosecuted if he did not pay); Wolhar, 809 F. Supp. at 1141 (stating that consumer is not responsible for deciding between two possible interpretations); NAT'L CONSUMER LAW CTR., supra note 33, § 5.5.2.5.6.1, at 153 (discussing case law).

114. The FDCPA prohibits " $[\mathrm{t}]$ he false representation or implication that any individual is an attorney or that any communication is from an attorney." 15 U.S.C. §1692e(3) (2000); see, e.g., Taylor v. Perrin, Landry, deLaunay \& Durand, 103 F.3d 1232, 1238 (5th Cir. 1997) (holding creditor liable as debt collector for using letterhead and facsimile signature of lawyer not participating in collection process); United States v. Cent. Adjustment Bureau, Inc., 667 F. Supp. 370, 379 (N.D. Tex. 1986) (debt collector violated statute by using form "attorney letters"), aff'd as modified, 823 F.2d 880 (5th Cir. 1987); see also FTC Staff Commentary, supra note 11, at 50,105 ("A debt collector may not send a collection letter from a 'Pre-Legal Department,' where no legal department exists").

115. 988 F.2d at 1316 . 
that the letters came from an attorney. ${ }^{116}$ Unfortunately, this was a false and misleading representation because the attorney did not review the debtor's file and did not even see the collection letters before they were mailed. ${ }^{117}$ In no sense, therefore, could it be said that the letters were from an attorney. Yet the letters stated that the attorney was suggesting that certain measures be taken "to further implement the collection of [the] seriously past due account." "118 The attorney had played no role in trying to collect the consumer's debt, thus confirming the false representation about the origin of the collection letter. ${ }^{119}$ It was also clear that the mass mailing in this case constituted a false, deceptive, or misleading communication. ${ }^{120}$

An attorney who wants to use the power of his position to elicit a consumer's response must be personally and directly involved in the collection process if he hopes to avoid liability under $\S 1692 \mathrm{e}^{121}$ It is evident that an attorney's letter is more likely to catch the consumer's attention, and it is this reality that leads to the collaboration between the creditor and the attorney. There is nothing inherently wrong with such an alliance, but the parties must be careful not to leave the impression that an attorney is intimately involved with the file if in fact he merely lends his name to the transaction as if it were just a legal endorsement.

It was well nigh an impossibility for the attorney in Avila v. Rubin ${ }^{122}$ to review 270,000 letters annually, and yet all those letters went out on an attorney's letterhead. ${ }^{123}$ This achievement may be evidence of the economic efficiency of the mass-mailing strategy, but the technique employed to attain that objective falls within the false, deceptive, or

\footnotetext{
116. Id. at 1320 .

117. Id.

118. Id. at 1317.

119. The court made its point as follows: "[T] he fact that Jackson played virtually no day-to-day role in the debt collection process supports the conclusion that the collection letters were not 'from' Jackson in any meaningful sense of that word." Id. at 1320; see also Nielsen v. Dickerson, 307 F.3d 623, 635 (7th Cir. 2002) ("[The attorney], as a legal professional, was not involved in . . the debt collection process in any meaningful sense.").

120. Clomon, 988 F.2d at 1321

121. See, e.g., Miller v. Wolpoff \& Abramson, L.L.P., 321 F.3d 292, 306 (2d Cir. 2003) (requiring that an attorney actually have participated in the collection process); Boyd v. Wexler, 275 F.3d 642, 644 (7th Cir. 2001) (finding that reasonable jury could infer that the volume of collection letters prevented attorney from reviewing them); Russey v. Rankin, 911 F. Supp. 1449, 1458 (D.N.M. 1995) (finding an attorney liable under $\S 1692 \mathrm{e}$ for cursorily signing collection letter); Masuda v. Thomas Richards \& Co., 759 F. Supp. 1456, 1461 (C.D. Cal. 1991) (finding collector's use of attorney form letter not only violated $\S 1692 \mathrm{e}$ but was also unfair and unconscionable under $\S$ $1692 f)$.

122. 84 F.3d 222 (7th Cir. 1996).

123. Id. at 225 .
} 
misleading category included in $\S 1692$ e. ${ }^{124}$ This is so because in an Avila-type case, an attorney has no time to review the files and has no real professional involvement in the transactions. The demand for the exercise of such professional judgment does not in any way detract from the importance of paralegals or other legal assistants, ${ }^{125}$ but the point here is that an attorney cannot delegate his professional judgment to others just to set production records by accelerating the collection process.

In Nielsen $v$. Dickerson, ${ }^{126}$ the attorney knew the identities of the consumers who were to receive the collection letters, but the letters were still form letters containing only basic information about the debt. ${ }^{127}$ The attorney's most serious involvement related to verifying whether delinquent debtors had already filed bankruptcy and screening out debtors in certain states. ${ }^{128}$ The attorney had no authority to engage the debtor in a payment plan or to take legal action to recover the debt. ${ }^{129}$ Like the attorney in Avila, the Nielsen attorney lent his name to the transaction as a convenient way of pressuring the consumer into compliance. ${ }^{130}$ It is not sufficient for an attorney simply to use a form letter without exercising his independent professional judgment in the collection process. ${ }^{131}$ The mailing of computer-generated form letters bearing an attorney's facsimile-stamped signature does little to inspire confidence about the attorney's professional role, although it may have

124. The form letters in Avila were "mass-produced and . . . mechanically signed "Albert G. Rubin' under his 'attorney' letterhead." Id. at 228. In the year before the lawsuit was filed, 270,000 of the mass-produced letters went out to consumers. Id. The argument for economic efficiency did not impress the Avila court because the attorney did not form any professional judgment about the cases involved. Id. A similar situation prompted the court in Clomon v. Jackson to make the following point:

It is apparent that mass mailing may sometimes be the only feasible means of contacting a large number of delinquent debtors, particularly when many of those debtors owe relatively small sums. But it is also true that the FDCPA sets boundaries within which debt collectors must operate. No mass mailing technique is permissible-regardless of how effective it might be - if that technique constitutes a false, deceptive, or misleading communication.

988 F.2d at 1321

125. In Avila, the defendants argued that holding the attorney liable would "condemn the use of paralegals and assistants in a law office." 84 F.3d at 229. The Avila court recognized that it was the lawyer's duty to supervise a paralegal's work. $I d$. at 229-30.

126. 307 F.3d 623 (7th Cir. 2002).

127. Id. at 636 .

128. Id.

129. Id. at 638; see also NAT'L CONSUMER LAW CTR., supra note 33, § 5.5.6, at 175 (discussing the Seventh Circuit's reasoning in Nielsen v. Dickerson).

130. Nielsen, 307 F.3d at 638 .

131. Id. 
the effect of convincing the consumer that he must respond in some fashion if he hopes to avoid litigation. ${ }^{132}$

An attorney may leave a false impression of his professional involvement by indicating that the account has been turned over to him for legal action. That strategy is designed to convince the debtor that a collector has instructed its lawyer to take the debtor to court and that the time for discussion has expired. In Schimmel v. Slaughter, ${ }^{133}$ William Slaughter was the general manager of Credit Bureau of Athens, but he was also an attorney at law. ${ }^{134}$ He thought he could get better results from the consumer by indicating in his collection letter that the account had been turned over to him for "suit purposes," and by signing the letter in his capacity as "Attorney at Law."135 Slaughter made it clear that he was writing "[a]s attorney for the Credit Bureau of Athens." 136 It did not take much to imagine that he wanted the debtor to infer that the account was now in the hands of an independent advocate who would try to win a judgment for his client. ${ }^{137}$ The reality was that "the account had not really been 'turned over' to [Slaughter]," for he was in fact the majority shareholder of Credit Bureau of Athens and could not retain himself. ${ }^{138}$ It was a deception calculated to produce a response from the consumer. ${ }^{139}$

There are variations in the deceptive strategy from time to time, but they invariably come back to the use of a name. In Schimmel it was the "attorney at law" designation that was misleading to the debtor, ${ }^{140}$ but in Veillard v. Mednick ${ }^{141}$ there was no such designation, and the court still

132. There was a similar scenario in Sonmore v. CheckRite Recovery Services, Inc., 187 F. Supp. 2d 1128 (D. Minn. 2001), where the court set the stage: "The parties do not dispute that Jon Hawks did not personally know Plaintiffs, review their letters, or review their files before sending them debt collection letters. The letters were computer generated form letters bearing a facsimile-stamp of Jon Hawks' signature." Id. at 1135.

133. 975 F. Supp. 1357 (M.D. Ga. 1997)

134. Id. at 1360.

135. Id.

136. Id.

137. Id. at 1362.

138. Id

139. Id. at 1362-63. The consumer in Avila v. Rubin, 84 F.3d 222 (7th Cir. 1996), faced a similar situation and the court highlighted the rationale for the collector's action:

An unsophisticated consumer, getting a letter from an "attorney," knows the price of poker has just gone up. And that clearly is the reason why the dunning campaign escalates from the collection agency, which might not strike fear in the heart of the consumer, to the attorney, who is better positioned to get the debtor's knees knocking. Id. at 229 .

140. 975 F. Supp. at 1360.

141. 24 F. Supp. 2d 863 (N.D. Ill. 1998). 
found the letter misleading and deceptive. ${ }^{142}$ This time the letterhead used was "Richard M. Mednick and Associates" and the signature was "J. Dancer for Richard M. Mednick, Debt Collector." "143 The court thought that it would be unusual for someone who was not a lawyer to use the phrase "and Associates" in the debt collection business, and that an unsophisticated consumer could reasonably believe that he was therefore dealing with a law firm that was prepared to sue him on the debt. ${ }^{144}$ It was significant here that the word "attorney" appeared nowhere in the collection letter, and thus the defendant felt confident that it would have taken some sophistication for a debtor to conclude that the letter had come from a lawyer. ${ }^{145}$ In some sense, the defendant had a point, since it is not that unusual to have other professionals use the designation "and associates." 146 Nevertheless, the court was convinced that under the circumstances, a consumer would be justified in thinking that "Richard Medick and Associates [was] a law firm prepared to take legal action on the debt."147

In Rumpler v. Phillips \& Cohen Associates, Ltd., a debtor was not successful when she tried to impress the court with a similar argument. ${ }^{148}$ The court compared the case to Clomon v. Jackson and reminded the parties that unlike Clomon, where the letterhead identified the writer as "Attorney-at-Law," 149 the letterhead in Rumpler was for "Phillips \& Cohen Associates, Ltd.," and there was no attorney designation in the letter. ${ }^{150}$ The only hitch was that the author of the Rumpler letter had used the "Esq." designation after his name, and the debtor thought that she could convince the court that this title was sufficient to indicate attorney status. ${ }^{151}$ It was not a bad try on the debtor's part, but the letter's author had also used the title "Executive Vice President" under his name, and the court was convinced that such a title had blunted the

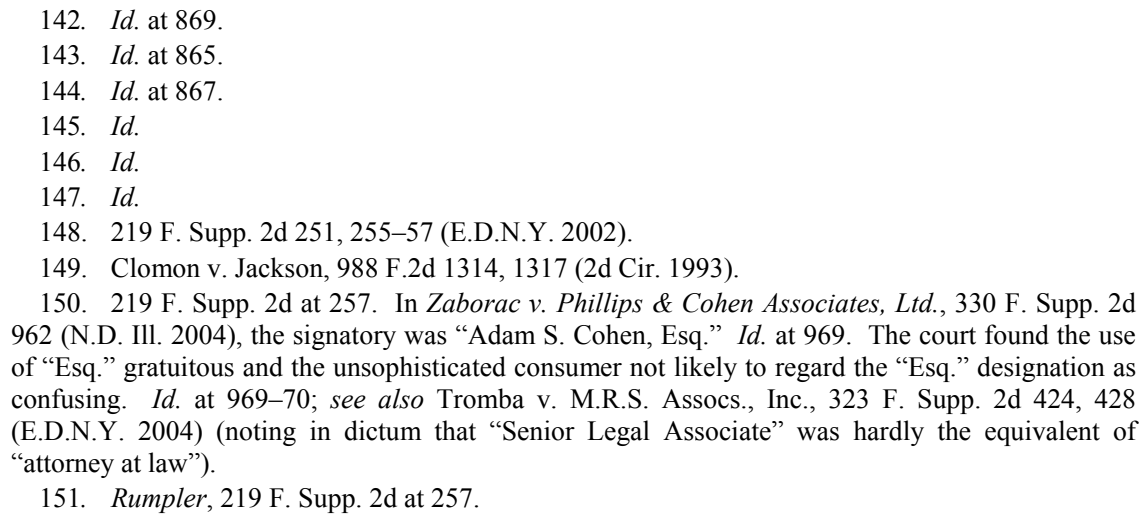
962 (N.D. Ill. 2004), the signatory was "Adam S. Cohen, Esq." Id. at 969. The court found the use of "Esq." gratuitous and the unsophisticated consumer not likely to regard the "Esq." designation as confusing. Id. at 969-70; see also Tromba v. M.R.S. Assocs., Inc., 323 F. Supp. 2d 424, 428 (E.D.N.Y. 2004) (noting in dictum that "Senior Legal Associate" was hardly the equivalent of "attorney at law").

151. Rumpler, 219 F. Supp. 2d at 257. 
effect of the "Esq." designation. ${ }^{152}$ The letter in Grief v. Wilson, Elser, Moskowitz, Edelman \& Dicker, $L L P^{153}$ was less objectionable because there was no mention of "Esq." or "attorney" and no other indication that the letter had come from a lawyer. There was no professional designation for the contact person identified in the letter, and the court was unpersuaded that there was a violation when such a person was merely identified as "Mr."154

\section{B. The Meaning of Language}

A careful choice of language will usually keep a debt collector out of trouble. For example, in Higgins v. Capitol Credit Services, Inc., ${ }^{155}$ the collection letter stated that "[i]f [the Power of Attorney] is approved, it could result in an attachment of [the debtor's] personal property and/or wages." $" 156$ The debtor objected to this language on the ground that it "would mislead an unsophisticated debtor to believe that the approval of the Power of Attorney, without more, would cause attachment of his property or garnishment of his wages."157

It is understandable that the court was not sympathetic to the debtor's plight in this context, for the language did not convey the message that approval of the power of attorney would lead to the legal remedies mentioned in the collection letter. ${ }^{158}$ The court explained "that the least sophisticated debtor understands that the phrase 'could result in' connotes a possible future occurrence and not an inexorable certainty." The debt collector did not have to go into detail on how it would accomplish the attachment or garnishment if it came to that. ${ }^{160}$ There was a difference between "could" and "would," and the collector's use of

152. Id.; see also Zaborac, 330 F. Supp. 2d at 969-70 (finding that the consumer did not meet burden of showing that an unsophisticated consumer would find use of "Esq." confusing). The designation in Rumpler was a little different from that in Clomon, where the collection letter identified the sender as "P.D. Jackson, Attorney at Law, General Counsel, NCB Collection Services." Clomon, 988 F.2d at 1317 (emphasis omitted). In that case, the least sophisticated consumer could not be criticized for believing that Jackson was acting as a lawyer. $I d$. at 1320-21.

153. 217 F. Supp. 2 d 336 (E.D.N.Y. 2002).

154. Id. at 341-42. The court explained: "The firm stationary [sic], on which the letter is written, does not include the names of attorneys or other firm personnel. As such, the least sophisticated consumer would not match Mr. DeGaetano's name to the name of an attorney in the firm." Id.

155. 762 F. Supp. 1128 (D. Del. 1991)

156. Id. at 1138 (first two alterations in original).

157. Id.

158. Id.

159. Id.

160. Id. 
the former term merely sent a message about the possibilities that lay ahead if the debtor continued his delinquency. ${ }^{161}$

In another case, the debt collector was not as careful with its message when it promised to release all liens when it received payment. ${ }^{162}$ One might logically ask why the collector referred to the release of nonexisting liens. In fact, the jury in Dutton found that the least sophisticated consumer could be misled into thinking that liens already existed on the property. ${ }^{163}$ The collector could not wiggle its way out of this predicament by underscoring its ability to obtain a lien if a judgment remained unsatisfied. ${ }^{164}$ There was nothing deceptive about identifying the available tools that might be available to the collector, but the bald assertion about releasing all liens once the debtor paid presupposed the existence of a lien. ${ }^{165}$ That is exactly the message the collector wanted to send, but in doing so, it used deceptive means to accomplish its objective.

At first blush, certain language does not seem to present a problem when taken in the abstract, but when it is put in context it can lead to more than one meaning. In Peters v. General Service Bureau, Inc., ${ }^{166}$ the debt collector's voluntary appearance letter stated that "if [the debtor] did not consent within five days, to appear voluntarily, the agency's 'only alternative' would be to request personal service by a city constable at his residence or place of employment."167 What was the meaning of "only alternative" in this context? The debtor argued that the statement was literally false because the local law also allowed service by certified mail or authorized agent. ${ }^{168}$ So the debtor's view was that the agency had other alternatives. On the other hand, the collector alleged that there was no viable alternative because service by certified mail was costly and did not produce the desired results. ${ }^{169}$ The court solved the problem by rejecting the contention that the collector's statement was literally false, because the statement did not say that service by constable was

\footnotetext{
161. Id. The court recognized that "[e]ven the least sophisticated debtor would take the statement in the May 10 letter to mean that failure to pay his debt might lead to garnishment of his wages or attachment of his property." Id. (emphasis added).

162. Dutton v. Wolpoff \& Abramson, 5 F.3d 649, 657 (3d Cir. 1993).

163. Id.

164. Id.

165. See id. at 657 (finding "merely that it could occur" is different from stating that it had occurred); see also Crossley v. Lieberman, 868 F.2d 566, 571 (3d Cir. 1989) (explaining that a collector falsely represented legal status of debt by implying that the case was already in litigation).

166. 277 F.3d 1051 (8th Cir. 2002).

167. Id. at 1053.

168. Id. at 1054 .

169. Id. at 1055 .
} 
"the only alternative under Nebraska law."170 It observed that the unsophisticated consumer test was a practical one, and that "statements that are merely 'susceptible of an ingenious misreading' do not violate the FDCPA."171

It is not easy to appreciate the ingenuity of reading "only" to mean "only," but it is perplexing that the court characterized the debtor's reading as an "ingenious misreading" under the circumstances. ${ }^{172}$ The collector's explanation of "only" led to the introduction of the adjective "viable" to qualify "alternative," a formulation which did not appear in its letter to the consumer. ${ }^{173}$ The court went along happily with the debt collector's position by suggesting that the debt collector would have failed the $\S 1692 \mathrm{e}$ test if it had advised the consumer that its only alternative under Nebraska law was service by a constable. ${ }^{174}$ This response is certainly not one that an unsophisticated consumer should be expected to make under the circumstances. It is akin to asking the consumer to read between the lines or to consider the various possibilities inherent in the use of the term "only." It is evident that even when the courts make some allowance for the consumer's lack of sophistication, they sometimes expect too much, and Peters is a good example of this phenomenon.

Despite cases like Peters, the courts do try their level best to give meaning to a debt collector's language. When a debt collector informs a debtor that the debtor will be subject to certain costs even before the collector files an action, there is an implication that the debtor is going to

170. Id. at 1056 (emphasis omitted).

171. Id. (citing White v. Goodman, 200 F.3d 1016, 1020 (7th Cir. 2000) (stating that the description on the back of a collection letter of the rights of Colorado residents, as required by Colorado law, should not be read to mean that residents of other states do not have such rights)); see also Morse v. Dun \& Bradstreet, Inc., 87 F. Supp. 2d 901, 904 (D. Minn. 2000) (finding that the Colorado notice provision in a collection letter was not false or misleading).

172. Applying the unsophisticated consumer test, the court concluded that "statements that are merely 'susceptible to an ingenious misreading' do not violate the FDCPA." Peters, 277 F.3d at 1056 (citing White, 200 F.3d at 1020). One wonders what was so ingenious about how the debtor interpreted the collector's language. A consumer would have thought that his failure to act might have led to a police constable at his door.

173. The omission of the word "viable" in the collection phrase was sure to leave the impression that the collector had no choice. So the consumer could either agree to appear voluntarily or face the prospect of a visit from a policeman.

174. See Peters, 277 F.3d at 1056 (stating that the letter would be false if it included the language "only alternative under Nebraska law"). In Avila v. Rubin, the Seventh Circuit took the view that a literally false statement violates the FDCPA as a matter of law. 84 F.3d 222, 227 (7th Cir. 1996). The Peters court did not want to go down this road because it stated that even assuming the falsity of the collector's statement, the statement would not mislead the consumer. See Peters, 277 F.3d at 1056 (stating that even if the letter was deemed literally false "it would not mislead because it effectively conveys the consequences of failing to sign and return"). 
lose his case because he will have no defense to the lawsuit. ${ }^{175}$ The insinuation here is that the debtor should give up promptly and avoid the sundry costs of defending an action that he cannot win. This is what the debt collector depends on-the fear that costs to the debtor will inevitably ensue once the debt collector takes legal action. In the same vein, if a debt collector refers to the possibility of garnishment after judgment is obtained, it leaves the debtor feeling that a judgment is inevitable, and it is this inevitability that is intended to prod the debtor into action. ${ }^{176}$ The debt collector hopes that a court will read this kind of language as merely indicating one of the avenues that will be available for enforcing a judgment once the debt collector obtains it. But a consumer might be persuaded more by the inevitability of the outcome than by the possibilities inherent in the enforcement options, and this is what the FDCPA is designed to avoid.

A debtor's complaint about a debt collector's language sometimes leaves a lot to be desired. In Goswami v. American Collections Enterprise, Inc., ${ }^{177}$ the collection letter contained a peculiar caption, "Settlement Offer \& Amnesty Period."178 The debtor went out on a limb and argued that the collector's use of the term "amnesty" in this context was deceptive because it suggested that criminal proceedings were pending. ${ }^{179}$ The court did not agree with the consumer and tied the term "amnesty" instead to the collector's offer of settlement. ${ }^{180}$ It was another

175. See Gradisher v. Check Enforcement Unit, Inc., 210 F. Supp. 2d 907, 914-17 (W.D. Mich. 2002) (finding that notices from collector, which stated that nonpayment of bad checks would result in criminal prosecution, violated the FDCPA when collector had no authority to commence criminal action); Fuller v. Becker \& Poliakoff, P.A., 192 F. Supp. 2d 1361, 1369 (M.D. Fla. 2002) (finding defendant's letter violated the FDCPA because an unsophisticated consumer would interpret it to mean "there was no chance in prevailing once a lawsuit was filed"); Spencer v. Henderson-Webb, Inc., 81 F. Supp. 2d 582, 591 (D. Md. 1999) (explaining that an attempt to collect other costs violates the FDCPA); Johnson v. Eaton, 873 F. Supp. 1019, 1024-25 (M.D. La. 1995) ("[T]he least sophisticated debtor would be induced to overlook and disregard his statutory right to dispute and verify the debt within 30 days.").

176. See Schimmel v. Slaughter, 975 F. Supp. 1357, 1363 (M.D. Ga. 1997) (stating that an unsophisticated debtor who received a letter from a lawyer using the words, "after judgment is obtained" would likely interpret it to mean there was no chance of prevailing, thus finding the language violated $\S 1692 \mathrm{e}(10)$ ); Dutton v. Wolhar, 809 F. Supp. 1130, 1141 (D. Del. 1992) (finding that the "once judgment is obtained" language violated the FDCPA), aff'd sub nom. Dutton v. Wolpoff \& Abramson, 5 F.3d 649 (3d Cir. 1993). In Gostony v. Diem Corp., the collector escaped liability although it threatened to file a lawsuit "and/or" garnish wages. The court did not view the threat as falsely implying that the collector had a present intent to garnish the consumer's wages before even filing suit. Gostony v. Diem Corp., 320 F. Supp. 2d 932, 941 (D. Ariz. 2003).

177. 377 F.3d 488 (5th Cir. 2004), cert. denied, 126 S. Ct. 331 (2005).

178. Id. at 492 .

179. Id. at 494-95.

180. The court stated that "[t]he 'amnesty' reference clearly refers to the debt forgiveness offer in the body of the letter and consumers, even unsophisticated consumers, would not believe 
attempt by a debtor to introduce a meaning that supported his allegation of deceit, although the collection language itself bore no relation to the debtor's interpretation of the heading. The debtor opted for a message that was designed to gain sympathy for him, although another meaning was plainly more relevant to his situation.

Even when one allegation seems hopeless, another may carry the day. So when the debt collector in Goswami misled the debtor into thinking that the creditor had limited the settlement offer to thirty days, the court found a violation of $\S 1692 \mathrm{e} .{ }^{181}$ The debt collector obviously had a strategy to goad the debtor into paying before time expired, even though the creditor had authorized the debt collector to give the debtor a discount at any time. ${ }^{182}$ It is true that the debtor must have been grateful for any possibility of a discount, but this did not give the debt collector license to mislead him.

Even though courts are generally well disposed towards settlement offers, they are not keen on giving a debt collector the leeway to deceive the consumer. ${ }^{183}$ The policy behind encouraging settlement offers is to resolve collection problems without the usual costs associated with a lawsuit. But this should not mean settlement at all costs, and the FDCPA does not grant the debt collector free rein to do as it pleases, all in the name of promoting its settlement strategy. When a debt collector urges a debtor to pay the amount demanded in order "to avoid the remedies available under the ... State laws," "184 that should give the debtor some clue about what the collector has in mind. But when the debt collector indicates in the same letter that it is making its "final demand" before it takes "“such actions," "185 the debtor should really begin to worry. Some

otherwise." Id. at 495. Settlement offers are consistent with the purpose of the FDCPA. See Lewis v. ACB Bus. Servs., Inc., 135 F.3d 389, 399 (6th Cir. 1998) (finding that "[a]llowing debt collectors to send such a letter [containing a settlement offer] is not only consistent with the Act but also may result in resolution of the debt without resorting to litigation").

181. 377 F.3d at 495-96. The collection letter misled the consumer with the following language: "Effective immediately, and only during the next thirty days, will our client agree to settle your outstanding balance due with a thirty percent $(30 \%)$ discount off your above balance owed." Id. at 492.

182. Id. at 495 .

183. See id. at 496 ("While we agree that it is important to permit collection agencies to offer settlements, that policy consideration does not remove collection agencies' obligation under the FDCPA to deal in a nondeceitful manner."); Buzoiu v. Risk Mgmt. Alternatives, Inc., No. 03-3579, 2003 WL 22938052, at *3-4 (E.D. Pa. Sept. 15, 2003) (collector's motion to dismiss denied where language about one-time offer was not clear); Jones v. Risk Mgmt. Alternatives, Inc., No. 02-C9392, 2003 WL 21654365, at*4 (N.D. Ill. July 11, 2003) (class action certified where consumer alleged that collector's offer was not really one-time offer).

184. Herbert v. Monterey Fin. Servs., Inc., 863 F. Supp. 76, 78 (D. Conn. 1994) (internal citation omitted).

185. Id. at 79 . 
debt collectors do not really intend their initial letter to be a final demand, although they may want the debtor to think so. Inevitably there is a follow-up letter, giving the debtor another few days to respond before the debt collector makes a final decision. This sequence is usually a carefully planned strategy to keep pressure on the debtor. It was the tactic that the debt collector used in Herbert ${ }^{186}$ to no great advantage, for the court recognized the collector's statement as "objectively false" and thus a violation of $\S 1692 \mathrm{e} .{ }^{187}$ The consumer was supposed to think that the debt collector was giving her one last chance before it acted, except that the "final demand" was not really final since it was followed by another communication that advised the debtor about a pending final decision. ${ }^{188}$

The debtor in Kimbro v. I.C. System, Inc. ${ }^{189}$ tried to use Herbert to bolster her claim of falsehood when the debt collector made an offer of settlement that was supposed to expire within ten days. ${ }^{190}$ But there was a different situation in Kimbro. ${ }^{191}$ Unlike Herbert, there was no "final demand," no indication of a one-time offer, and no threat of legal action. ${ }^{192}$ The debtor in Kimbro was unable to show that the debt collector would not honor its promise of a discount if the consumer paid within ten days or a reasonable period thereafter. ${ }^{193}$ There was also no evidence that the debt collector would reject the debtor's attempts to arrange a payment plan if the debtor could not pay off the debt immediately. ${ }^{194}$ The debtor could hardly prove that the collector's statement was false under these circumstances.

\section{The Amount of the Debt}

A debt collector can easily misstate the amount of the debt that the consumer owes by including costs and fees not yet due. This can be a winning strategy for the debt collector if the consumer is overwhelmed by the prospect of facing an inflated debt, for then he may succumb to the collector's demands. When the FDCPA enjoins the debt collector from misrepresenting the "character, amount, or legal status" of the

186. Id.

187. $I d$. at 80 .

188. Id. at $78-79$.

189. 336 F. Supp. 2d 188 (D. Conn. 2004).

190. Id. at $190-91$.

191. Id. at 192 .

192. Id.

193. Id.

194. Id. 
debt, ${ }^{195}$ it merely seeks to take away one of the weapons in the debt collector's arsenal. A debt collector's misstatement of the amount of the debt may lead the consumer to settle for a reduced amount, thinking all the while that he is getting a bargain.

The collector in Veach $v$. Sheeks ${ }^{196}$ knew full well what he was doing when he included in the amount of the debt legal penalties that a court had not yet awarded. ${ }^{197}$ What started out as a claim for $\$ 350$ eventually increased to $\$ 1050$, plus a reasonable attorney's fee and court costs, and the attorney justified the figure on the basis of treble damages. ${ }^{198}$ The only problem was that a court had to enter a judgment for such damages, and the collector's statement about such damages was premature. ${ }^{199}$ It was a misrepresentation of the debt. The remedy of treble damages was a creature of statute, and the debt collector could not include it in the amount of the debt without judicial approval. ${ }^{200}$

Even when a contract between the parties provides for costs and an attorney's fee, a debt collector must still clearly identify the amount of the debt for the consumer's benefit. In Fields v. Wilber Law Firm, ${ }^{201}$ a debt that started out as \$122.06 ended up eight months later as $\$ 388.54 .^{202}$ The consumer alleged that the collection letters were misleading because the debt collector did not explain how the balance had reached that figure, even though the contract allowed for certain costs. $^{203}$ The court concluded that the consumer had allegations sufficient to state a claim under $\S 1692 \mathrm{e}^{204}$

It is understandable that a court would look askance at this method of disclosure where the debt collector lumps all items together as the

\footnotetext{
195. 15 U.S.C. $\S 1692 \mathrm{e}(2)(\mathrm{A})(2000)$.

196. 316 F.3d 690 (7th Cir. 2003).

197. See id. at 694 ("[Collector] knew that [debtor] allegedly owed [creditor] $\$ 350 \ldots$. . [and] assum[ed] the outcome of future events in drafting his notice ....").

198. Id. at 691-92.

199. See id. at 693 ("Since Veach cannot be held liable for treble damages, court costs, or attorney's fees until there has been a judgment by a court, they cannot be part of the 'remaining principal balance' of a claimed debt.") (emphasis added).

200. Id. The collector in Veach tried to avoid liability by relying on the accuracy of the notice of claim and small claim summons. Id. However, another notice of claim contained the misleading information about the debt. Id. The court held that when there are two different versions of the amount of the debt, the communication may still violate the statute. Id. (citing Johnson v. Revenue Mgmt. Corp., 169 F.3d 1057, 1060 (7th Cir. 1999)).

201. 383 F.3d 562 (7th Cir. 2000).

202. Id. at 563 .

203. See id. at 563-64, 566 ("[Consumer] asserted that the collection letters ... were misleading under $\S 1692 \mathrm{e}$ " because "[n]owhere did [collector] explain that it was seeking attorneys' fees of $\$ 250 . ")$.

204. Id. at 565-66.
} 
account balance. It was particularly disconcerting in Fields because the debt collector sent out the initial letter some eight months after the consumer allegedly had incurred the charges. ${ }^{205}$ After a time memories fade, and a consumer may be hard pressed to recall the details of the transaction. He may just throw in the towel and pay off the "account balance" without understanding that it represents substantially more than the charges originally incurred. In this context, the debt collector has ample opportunity to create a false impression about the character of the debt, and the FDCPA therefore imposes an obligation on the debt collector to reveal the details of the amount it is seeking. The debt collector can fulfill its mission by itemizing the various charges so that there is no confusion about the character of the debt. ${ }^{206}$ While the debt collector in Fields was well within its rights to include an attorney's fee within its claim in light of the contractual terms between the creditor and the consumer, the collector still had an independent duty to be forthright about the elements of the balance due. ${ }^{207}$ It was not enough for the debt collector to provide a telephone number for the consumer to call if he had any questions. ${ }^{208}$ The obligation to comply with the statute cannot be wiped out by merely establishing lines of communication between the parties. ${ }^{209}$

The debt collector can also cause confusion for the consumer by listing the balance due as a certain amount plus interest and legal fees. Since the interest increases as the debt becomes more delinquent, the debt collector will wonder how it can disclose the interest as a part of the debt when it communicates with the consumer. The collector should disclose the amount of the debt, including the interest due, as of the date of the collection letter. ${ }^{210}$ This will give the consumer a firm idea of the

205. Id. at 563 .

206. As the court said in Fields, "[i]t would be difficult for [an unsophisticated consumer] to understand how a relatively modest fee for services rendered had tripled in size." Id. at 566.

207. Id.

208. Id. (citing Miller v. McCalla, Raymer, Padrick, Cobb, Nichols, \& Clark, L.L.C., 214 F.3d 872, 875-76 (7th Cir. 2000)).

209. Id.; see also Miller, 214 F.3d at 875-76 (holding that mere listing of a phone number does not satisfy the FDCPA even when the amount of debt changes daily because the collector could "state the total amount due - interest and other changes as well as principal — on the date the dunning letter was sent"); Validation Notice-Disclosure of Amount of the Debt: Part II, 36 CONSUMER CREDIT AND TRUTH-IN-LENDING COMPLiANCE REPORT 3 (Earl Phillips ed. Dec. 2004) (summarizing the Fields holding).

210. Miller, 214 F.3d at 875-76. The Seventh Circuit provided some safe-harbor language in Miller:

As of the date of this letter, you owe $\$$ _ [the exact amount due]. Because of interest, late charges, and other charges that may vary from day to day, the amount due on the day you pay may be greater. Hence, if you pay the amount shown above, an 
amount due as of that date, and does not leave him guessing about that element.

A reference to legal fees without an explanation can get a debt collector in trouble because a consumer will not usually owe any such fees when the debt collector sends its collection letter. That was the problem in McDowall v. Leschack \& Grodensky, P.C., ${ }^{211}$ in which the debt collector stated the balance due plus "interest and attorney's fees." 212 With respect to the attorney's fees, the collector's defense was that it had made no demand for legal fees, but had merely reminded the consumer of his contractual agreement to pay them. ${ }^{213}$ The court observed that the debt collector had listed the attorney's fees as a part of the balance due, thus creating the impression that such fees were already a part of the debt. ${ }^{214}$ But such fees were not due when the debt collector sent out its letter, and the consumer could have been misled into thinking that she owed an amount well beyond that which could be enforced. ${ }^{215}$ The debt collector thought that it would be forgiven for referring to legal fees if it used language later in the letter indicating that the consumer had agreed in the credit card agreement to pay a reasonable attorney's fee. ${ }^{216}$ The collector had already listed the attorney's fees as part of the balance due, and a subsequent asterisk with a reference to the credit card agreement did not undo the damage already done by the confusing language. ${ }^{217}$

Sometimes a consumer thwarts a debt collector's litigation plans by paying the outstanding debt to avoid trial. When the collector tries later

adjustment may be necessary after we receive your check, in which event we will inform you before depositing the check for collection. For further information, write the undersigned or call 1-800-[phone number].

Id. (alterations in original).

211. 279 F. Supp. 2d 197 (S.D.N.Y. 2003).

212. Id. at 198 (internal citation omitted).

213. Id. at 200

214. Id.

215. Id. In Person v. Stupar, Schuster \& Cooper, S.C., 136 F. Supp. 2d 957 (E.D. Wis. 2001), the collection letter stated that the debtor owed "\$987.71, plus attorney's fees." Id. at 959. The court held that it was not irrational or unrealistic to view the letter as meaning that the debtor owed a principal balance and "an indeterminate amount of attorney fees." Id. at 963 . The collectors sought refuge in the "safe-harbor" language of Bartlett v. Heibl, 128 F.3d 497, 501-02 (7th Cir. 1997), but that language did not include the phrase "plus attorney's fees," and the case essentially revolved around the consumer's confusion under $\S 1692 \mathrm{~g}$ rather than the collector's deception under $\S 1692 \mathrm{e}$. Person, 136 F. Supp. 2d at 963-64; see also Veach v. Sheeks, 316 F.3d 690, 692 (7th Cir. 2003) (finding collector liable for including in amount of debt legal penalties not yet awarded by court).

216. See McDowall, 279 F. Supp. 2d at 200 (rejecting the collectors' argument that the collection letter did not demand attorney's fees because it merely referred to the consumer's prior agreement to pay reasonable attorney's fees).

217. Id. The collection letter did not clarify that the consumer did not owe any attorney's fees at the time the letter was written. $I d$. 
to recover court costs, it may find an uncooperative debtor who questions the legitimacy of its claim. One might wonder whether there can be court costs if there has been no trial. The debtor in Shula v. Lawent ${ }^{218}$ challenged whether he owed anybody for such costs when he had already paid his debt before entry of a judgment. ${ }^{219}$ If the court had awarded costs, they certainly would have become part of the debt. But there was no such award in Shula, and the debtor was justified in querying the collectors' claim as false and misleading. ${ }^{220}$

The collection letter stated that the debtor owed the collectors for court costs, ${ }^{221}$ a claim that could hardly be justified under the circumstances without a court order. In any event, the costs, if any, would have been due the creditor and not the collectors. Thus the collectors' assertion that the debtor owed them was inaccurate. The collectors were really suing on behalf of the creditor, and their letter demanding that the debtor should pay them, because the debtor owed them, was false and misleading under $\S 1692 \mathrm{e}^{222}$

The debt collector has a duty to disclose to the debtor the amount of the debt, the current obligation, "not what the final, worst-case scenario could be." 223 It is, therefore, not a good strategy for a debt collector to include in the amount of the debt the various costs and penalties that might ensue after a judgment is obtained. ${ }^{224}$ From the collector's perspective, the more items the collector can add to the debt, the greater the balance due will be. This inflated figure will doubtless make an impression on the debtor. A false representation of the amount of the debt is supposed to produce dividends for the debt collector, because it gives the collector some leeway in settling the debt for a lesser amount that may come close to what the collector hoped to recover anyway. Nevertheless, a collector's strategy can backfire when the balance allegedly due greatly exceeds anything the debtor recognizes. In Goins

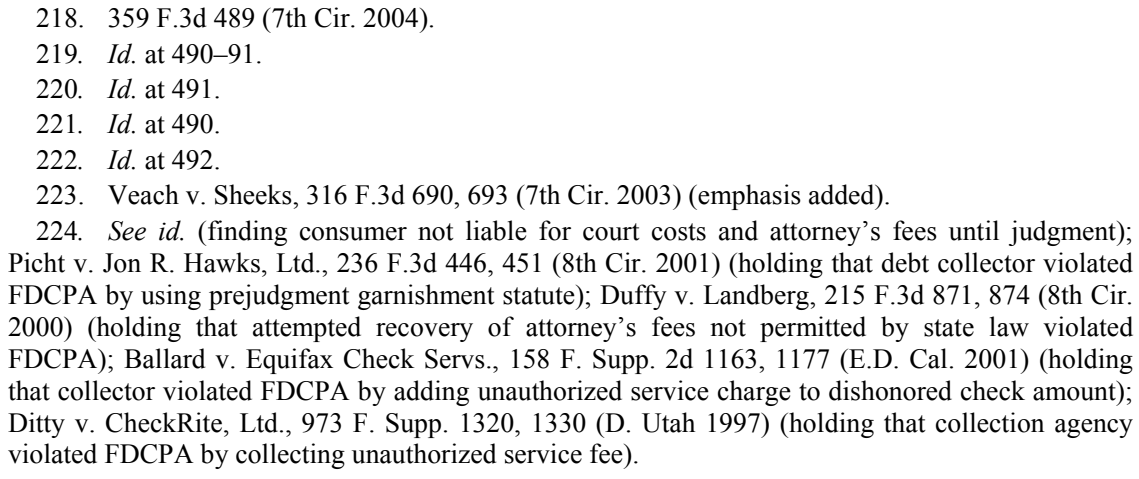
Picht v. Jon R. Hawks, Ltd., 236 F.3d 446, 451 (8th Cir. 2001) (holding that debt collector violated FDCPA by using prejudgment garnishment statute); Duffy v. Landberg, 215 F.3d 871, 874 (8th Cir. 2000) (holding that attempted recovery of attorney's fees not permitted by state law violated FDCPA); Ballard v. Equifax Check Servs., 158 F. Supp. 2d 1163, 1177 (E.D. Cal. 2001) (holding that collector violated FDCPA by adding unauthorized service charge to dishonored check amount); Ditty v. CheckRite, Ltd., 973 F. Supp. 1320, 1330 (D. Utah 1997) (holding that collection agency violated FDCPA by collecting unauthorized service fee). 
v. JBC \& Associates, P.C., ${ }^{225}$ the collection letter identified one creditor but associated twenty-two returned checks with the balance due that creditor, instead of only the two that were relevant. ${ }^{226}$ The letter therefore left the impression that the amount sought, \$10,277.56, concerned only debts owed to the identified creditor, and nowhere indicated that the amount included debts owed to other merchants. ${ }^{227}$ Furthermore, although the letter stated that the debtor might be subject to statutory penalties "as determined by the court," the debt collector designated the balance as $\$ 10,277.56$, which purported to include the potential statutory damages that were available under state law for returned checks. ${ }^{228}$ The inclusion of such damages for other checks, not related to the payee of the two checks in contention in Goins, amounted to false representation of the amount of the debt owed, and the debtor could not be faulted for complaining about the misleading nature of the communication. $^{229}$

\section{Identifying the Purpose of the Communication}

It is also a violation if, in its initial communication, a debt collector does not disclose that it is trying to collect a debt and that it will use any information it obtains for that purpose. ${ }^{230}$ Subsequent communications need only indicate that the communication is from a debt collector and may exclude the other collection language required in the initial communication. ${ }^{231}$ Before the statute was amended in $1996,{ }^{232}$ the debt collector had to include the $\S 1692 \mathrm{e}(11)$ language in all debt collection communications, including those with other parties besides the

\footnotetext{
225. 352 F. Supp. 2d 262 (D. Conn. 2005).

226. Id. at 269 .

227. Id.

228. Id.

229. Id. The collector really painted the worst-case scenario, and the requirement of stating the amount of the debt is intended to inform the debtor of his obligation only. Id. (citing Veach, 316 F.3d at 693).

230. 15 U.S.C. $\S 1692 \mathrm{e}(11)(2000)$.

231. Id.

232. See Omnibus Consolidated Appropriations Act of 1997, Pub. L. No. 104-208, § 2305, 110 Stat. 3009, 3009-425 (1996).
} 
consumer, ${ }^{233}$ but the amended statute is intended to regulate only communications with the consumer. ${ }^{234}$

In fulfilling its obligation under $\S 1692 \mathrm{e}(11)$, a debt collector does not have to use the exact language contained in the statute, as long as it conveys the statutory message effectively. The debt collector in Ross $v$. Commercial Financial Services, Inc. ${ }^{235}$ tried to make its letter more impressive by stating that it was a "different kind of debt collection company." "236 Perhaps the collector sought some variation on the theme, but the court would not accept the debtor's contention that the defendant's language would mislead a consumer into thinking that the defendant was anything but a debt collector. ${ }^{237}$ The court's reaction was that "[a] 'debt collection company' is a 'debt collector' in anyone's vernacular." 238

If a person's contact with a consumer does not constitute an initial communication, then there is no need for the $\S 1692 \mathrm{e}(11)$ language to be included in a letter that merely inquires whether the consumer has filed for bankruptcy. The defendant in Buckley v. Bass \& Associates ${ }^{239}$ made a delicate inquiry about a "possible bankruptcy," listing the creditor's name and account number. ${ }^{240}$ It was not a demand for payment and did not indicate the amount of the debt. But the defendant's request for bankruptcy information was obviously intended to guide the defendant's strategy, since the defendant was in the business of representing creditors

233. Before the 1996 amendment, the $\S 1692$ e violation read as follows:

Except as otherwise provided for communications to acquire location information under section $1692 \mathrm{~b} \ldots$, the failure to disclose clearly in all communications made to collect a debt or to obtain information about a consumer, that the debt collector is attempting to collect a debt and that any information obtained will be used for that purpose.

15 U.S.C. $\S 1692 \mathrm{e}(11)$ (Supp. II 1979).

234. See 15 U.S.C. $§ 1692$ e(11) (2000) (outlining the requirement that the debt collector, in its first communication with the consumer, must inform the consumer of the purpose of the communication); see also Conboy v. AT \& T Corp., 241 F.3d 242, 257 (2d Cir. 2001) (holding that the plaintiffs had no claim under $\S 1692$ e because plaintiffs were not consumers); NAT'L CONSUMER LAW CTR., supra note 33, $\S 5.5 .14 .1$, at 192 (explaining that the amended statute only imposed its requirements on communications with the consumer).

235. 31 F. Supp. 2d 1077 (N.D. Ill. 1999).

236. Id. at 1079 .

237. See id. at 1080 (stating that "[c]oupled with the bold-faced statement that the letter is 'an attempt to collect a debt,' it is impossible to conclude that the letter is in any way misleading").

238. Id. at 1079; see also Pipiles v. Credit Bureau of Lockport, Inc., 886 F.2d 22, 26 (2d Cir. 1989) (not necessary to quote the $\$ 1692$ e(11) language); Sandlin v. Shapiro \& Fishman, 919 F. Supp. 1564, 1568 (M.D. Fla. 1996) (same); NAT'L CONSUMER LAW CTR., supra note 33, § 5.5.14.1, at $191-92 \&$ n.682 (discussing cases).

239. 249 F.3d 678 ( 7 th Cir. 2001).

240. Id. at 679 . 
in consumer bankruptcies. ${ }^{241}$ If the consumer had admitted in her response that she had filed for bankruptcy, the defendant would have known that it had to file a claim in bankruptcy or seek reaffirmation of the debt if it was secured. ${ }^{242}$ If the debtor had not filed, then presumably the defendant could have then sent a collection letter, for there would be no issue of an automatic stay. ${ }^{243}$

In Buckley, the Seventh Circuit was not prepared to preclude inquiries which merely solicited information from the debtor about his bankruptcy status, and thus agreed with the defendant that the statute did not impose an obligation on the defendant to admit that it was trying to collect a debt, and that it would use any information obtained in the process for that purpose. ${ }^{244}$ Among the various blank spaces on the information sheet sent to the debtor was one regarding the debtor's "intent." The court readily conceded that a consumer might read this inquiry about intent as an indirect demand for payment. ${ }^{245}$ If the defendant routinely sent this inquiry to every debtor without any basis for suspecting bankruptcy, such debtors might view the letter as a threat to force them into bankruptcy if they did not pay. ${ }^{246}$

There were other possibilities, of course, foremost among them being that the defendant was only in the business of dealing with creditors' claims in bankruptcy, rather than being in the collection business as such. If so, the defendant's inquiry would not be a precursor to a collection letter, but rather to a claim in bankruptcy, which would fall outside the FDCPA. The Seventh Circuit did not have to choose between these possibilities, for the debtor was looking for a declaration from the court that the defendant's letter was, on its face, an initial communication which brought $\S 1692 \mathrm{e}(11)$ into play. ${ }^{247}$ This search for a per se rule of illegality was unsuccessful only because the court was unwilling to treat all inquiries about bankruptcy as an initial communication in connection

241. Id.

242. Id. at 680 (citing Cox v. Zale Del., Inc., 239 F.3d 910, 912-13 (7th Cir. 2001)); see also Aiello v. Providian Fin. Corp., 239 F.3d 876, 878-79 (7th Cir. 2001) (discussing options for creditors whose debtors are in bankruptcy); Chase Automotive Fin., Inc. v. Kinion (In re Kinion), 207 F.3d 751, 756 (5th Cir. 2000) (discussing the purpose of reaffirmation in bankruptcy); In re Turner, 156 F.3d 713, 715 (7th Cir. 1998) (discussing reaffirmation).

243. See 11 U.S.C. § 362(a) (2000) (providing for automatic stay).

244. See Buckley, 249 F.3d at 681 ("Given that a debt collector or other creditor's agent has a legitimate interest in finding out the debtor's bankruptcy status, we do not think the Act makes such inquiries illegal per se.”); see also 15 U.S.C. § 1692e(11) (2000) (stating that a collector's failure to include the necessary warning to the consumer is a violation).

245. Buckley, 249 F.3d at 681.

246. Id.

247. Id. at 681-82. 
with the collection of a debt. ${ }^{248}$ The plaintiff would have survived the motion to dismiss if it had not pressed for such a categorical approach to the defendant's letter.

\section{E. Prodding the Consumer}

A defendant need not fear a violation unless its contact with a consumer is "in connection with the collection of any debt." 49 After all, $\S 1692$ e regulates the representations that a debt collector can make in its efforts to recover an outstanding debt. If the debt is not in default, it is not subject to the FDCPA. In Bailey v. Security National Servicing Corp. ${ }^{250}$ the consumers hoped to stave off the lender's enforcement under the original note by entering into a forbearance agreement with the Department of Housing and Urban Development that temporarily superseded the original obligation. The servicers of the forbearance agreement thought they were being helpful by reminding the consumers of the next four payments due and of the consequences that might ensue from the consumers' delinquency under the new plan. ${ }^{251}$ Unlike the situation in Bartlett v. Heibl, ${ }^{252}$ the servicers in Bailey made no demands on the consumer and were not attempting to collect any debt. ${ }^{253}$ The forbearance agreement had given the consumers a new lease on life, and thus the servicers' letter did not relate to any existing default. ${ }^{254}$ The servicers' warning about the grave consequences of a default under the forbearance agreement did not rise to the level of a collection letter. There could be no attempt at collection unless the consumers failed to keep their promise. ${ }^{255}$ The letter to the consumers really contained only information about the status of the account and underscored the importance of timely payments under the new arrangement. ${ }^{256}$ It could

248. See id. at 682 (stating that the consumer did not want discovery in order to prove that the defendant was collecting debts, and that the consumer wanted a per se rule that the letter was an initial communication under $\S 1692 \mathrm{e})$.

249. 15 U.S.C. $\S 1692$ e. The statute provides that "[a] debt collector may not use any false, deceptive, or misleading representation or means in connection with the collection of any debt." Id.

250. 154 F.3d 384 (7th Cir. 1998).

251. Id. at 386 .

252. 128 F.3d 497, 501 (7th Cir. 1997). The collection letter in Bartlett plainly said that if the debtor did not pay within a week, he was going to be sued. Id.

253. Bailey, 154 F.3d at 388 .

254. Id. at 389 .

255. Id. The court made the point: "At most the letter contains a warning that a failure to pay the monthly installments (in other words, default a second time) will mean that the forbearance agreement becomes null and void, resulting in acceleration." Id.

256. Id. There was similarly no communication in connection with the collection of a debt in Guerrero v. RJM Acquisitions, LLC, No. 03-00038, 2004 U.S. Dist. LEXIS 15416, at *33 (D. Haw. 
not, therefore, be regarded as a communication in connection with the collection of a debt.

Sometimes a debt collector is accused of violating the FDCPA by trying to collect a debt that is barred by the statute of limitations. The statute prohibits the debt collector from misrepresenting the legal status of the debt, ${ }^{257}$ and consumers usually take the position that a debt collector has no business pursuing a debt which it knows cannot be judicially enforced if the statute of limitations has expired. When the collector merely tries to collect the debt without threatening litigation, the courts usually find no violation. ${ }^{258}$ This is so because the statute of limitations generally bars the remedy, but does not extinguish the debt. ${ }^{259}$ On the other hand, if the state statute extinguishes the debt, it is deceptive for a collector to try to collect it. ${ }^{260}$

There was no doubt about the collector's strategy in Goins v. JBC \& Associates, P.C. ${ }^{261}$ when the collector threatened to seek "appropriate relief before a court of proper jurisdiction" 262 even though the statute of limitations had expired. The collector thought it had a good defense to any charge of a violation because the consumer could waive the statute of limitations, thus giving vitality to the debt collector's claim. ${ }^{263}$ However, the court recognized that the statute of limitations would be a complete defense to any suit and that the threat of suit was at best a

July 9, 2004). The previous owner of the account merely informed the debtor that the account was sold to another entity. There was no request or demand for payment. Id. at *32-33.

257. It is a violation for a collector to represent falsely "the character, amount, or legal status of any debt." 15 U.S.C. $\S 1692 \mathrm{e}(2)(\mathrm{A})(2000)$.

258. See Freyermuth v. Credit Bureau Servs., Inc., 248 F.3d 767, 771 (8th Cir. 2001) (holding that "in the absence of a threat of litigation," no violation of the FDCPA has occurred); Wallace v. Capital One Bank, 168 F. Supp. 2d 526, 529 (D. Md. 2001) (finding no violation of FDCPA when debt collector did not try to trick debtor into waiving his rights); Shorty v. Capital One Bank, 90 F. Supp. 2d 1330, 1332 (D.N.M. 2000) (finding that where the letter did not threaten a lawsuit, there was no violation of the FDCPA).

259. See Wallace, 168 F. Supp. 2d at 528 (finding no violation where consumer was not tricked into giving up his remedy); Walker v. Cash Flow Consultants, Inc., 200 F.R.D. 613, 616 (N.D. Ill. 2001) (finding no violation where collector tried to collect debt on which litigation was time-barred); NAT'L CONSUMER LAW CTR., supra note 33, § 5.5.2.9.3, at 166 (discussing the filing of time-barred suits).

260. See, e.g., Wis. Stat. Ann. $§ 893.05$ (West 2004) ("When the period within which an action may be commenced on a Wisconsin cause of action has expired, the right is extinguished as well as the remedy."); see also Klewer v. Cavalry Invs., LLC, No. 01-C-541-S, 2002 WL 2018830, at *3 (W.D. Wis. Jan. 30, 2002) (finding that because Wisconsin's statute of limitations extinguished the debt, it was deceptive for the collector to pursue collection); First Nat'l Bank of Madison v. Kolbeck, 19 N.W.2d 908, 909 (Wis. 1945) (stating that the statute of limitations eliminates the right to collect the debt and the remedy).

261. 352 F. Supp. 2d 262 (D. Conn. 2005).

262. Id. at 265 .

263. See id. at 272 (stating that the defendants' position was that the statute of limitations was not a jurisdictional bar, but simply an affirmative defense that could be waived). 
misleading representation. ${ }^{264}$ When there is no threat, however, the collector's fulfillment of his statutory obligation to provide a validation notice does not cause a violation. In doing so, the collector is simply following the requirements of $\S 1692 \mathrm{~g}$ to give the consumer salient information about the consumer's debt and verification rights, and the statutory language does not encourage or tolerate any threat from the collector. ${ }^{265}$ Nevertheless, one wonders whether the absence of any language in the collector's communication relating to the statute of limitations may mislead a consumer into thinking that the debt collector is trying to collect an enforceable debt. If the consumer makes a partial payment to keep the collector at bay, he may find himself reviving the debt and thus removing the statute of limitations as a defense. ${ }^{266}$ There is, of course, a world of difference between inducing a consumer to make a payment that will lead to a waiver and merely providing a validation notice. $^{267}$ In the latter case, the debt collector is performing its statutory duty as a part of a routine request for payment. ${ }^{268}$ The statute requires something more for a debt collector to be guilty of a violation, so there should be no problem unless the consumer can expose some strategy by the collector to lure him into a waiver of the statute of limitations.

264. Id.; see also Kimber v. Fed. Fin. Corp., 668 F. Supp. 1480, 1489 (M.D. Ala. 1987) (stating that the threat of a suit after the statute of limitations has run is deceptive).

265. See Shorty v. Capital One Bank, 90 F. Supp. 2d 1330, 1332 (D.N.M. 2000) (finding that a debt validation containing mandatory statutory language did not violate the FDCPA); Aronson v. Commercial Fin. Servs., Inc., No. 96-2113, 1997 WL 1038818, at*3 (W.D. Pa. Dec. 22, 1997) (same), aff'd, 162 F.3d 1150 (3d Cir. 1998); Jang v. A.M. Miller \& Assocs., Inc., No. 95-C-4919, 1996 WL 435096, at *5 (N.D. Ill. July 31, 1996) (same), aff'd, 122 F.3d 480 (7th Cir. 1997).

266. See United States v. Culver, 958 F.2d 39, 41 (4th Cir. 1992) (stating that partial payment allows cause of action to come into existence again); Wallace v. Capital One Bank, 168 F. Supp. 2d 526,528 (D. Md. 2001) (stating that a letter seeking voluntary payment is not automatically violative because statute of limitations has run); Jenkins v. Karlton, 620 A.2d 894, 904 (Md. 1993) (stating that acknowledgement of a debt removes the bar set by the statute of limitations).

267. See Shorty, 90 F. Supp. 2d at 1332 (indicating that debt collection letters following $§ 1692 \mathrm{~g}$ are not misleading); Aronson, $1997 \mathrm{WL} 1038818$, at *3 (explaining that following proper language in a collection letter does not misrepresent the debt).

268. See 15 U.S.C. $§ 1692 \mathrm{~g}$ (2000) (allowing creditors to send debtors written notice if statutory requirements are met). The validation notice does not constitute a threat, but is merely a provision that requires the collector to give the consumer basic details about the debt and explains the consumer's right to query the debt. Id. Thus, a collector must give the notice whether or not it is accompanied by the collector's threat to sue. Such notice is simply a part of the collection process, and the collector's inclusion of the notice in his collection attempt does not give rise to a cause of action. See Perretta v. Capital Acquisitions \& Mgmt. Co., No. C-02-05561, 2003 WL 21383757, at *3 (N.D. Cal. May 5, 2003) (finding that notice and letter threatening "further steps" went beyond the statutory requirement and constituted a violation of the FDCPA); Reese v. Arrow Fin. Servs., LLC, 202 F.R.D. 83, 92 (D. Conn. 2001) ("Where debt collectors have not threatened collection action, courts have not found FDCPA violations solely on the mailing" of a notice). 
In Aronson v. Commercial Financial Services, Inc., ${ }^{269}$ the consumer thought he was making some headway when he advised the collector that the debt was barred by the statute of limitations, only to hear the collector reply that the "statute of limitations ... only has to do with the length of time that it can show on your credit report.",270 This kind of language can lead a consumer to forego his defense of the statute of limitations, and so the court in Aronson viewed the debt collector's statement as misleading under $\S 1692 \mathrm{e}^{271}$ It was understandable that the court would take this approach, since this went beyond a mere validation notice. The debt collector made a definitive statement about the character of the debt, and the consumer had no clue that he could not rely on the collector's confident assertion about the relationship between the statute of limitations and the credit report. In the final analysis, however, the debt collector was rescued by the bona fide error defense, which the court deemed applicable even though the collector's error was one of legal judgment. ${ }^{272}$

A collector does not have to use outright threats in order to violate the statute. A court may find an implied threat of litigation through the cumulative effect of the collection language and other communications from the collector. Although a message on law firm letterhead is not sufficient by itself to be regarded as threatening, ${ }^{273}$ other factors may tilt the scales in favor of a threat. This was the case in Gervais v. Riddle \& Associates, P.C., ${ }^{274}$ when the defendant left telephone messages for the

269. No. 96-2113, 1997 WL 1038818, at *1 (W.D. Pa. Dec. 22, 1997), aff'd, 162 F.3d 1150 (3d Cir. 1998).

270. Id. at $* 1$

271. Id. at *4.

272. Id. at *4. A collector may use the bona fide error defense if it can show "by a preponderance of evidence that the violation was not intentional and resulted from a bona fide error notwithstanding the maintenance of procedures reasonably adapted to avoid any such error." 15 U.S.C. $\S 1692 \mathrm{k}(\mathrm{c})$ (2000). The Aronson court has joined with a number of courts in resisting the majority position that the defense is restricted to errors of a clerical nature. Compare Johnson v. Riddle, 305 F.3d 1107, 1123 (10th Cir. 2002) (stating that $\S 1692 \mathrm{k}(\mathrm{c})$ does not limit the bona fide error defense to clerical errors), and Frye v. Bowman, Heintz, Boscia \& Vician, P.C., 193 F. Supp. 2d 1070, 1085 (S.D. Ind. 2002) (same), and Taylor v. Luper, Sheriff \& Niedenthal Co., 74 F. Supp. 2d 761, 765 (S.D. Ohio 1999) (same), with Picht v. John R. Hawks, Ltd., 236 F.3d 446, 451 (8th Cir. 2001) (finding that mistake in legal judgment is not bona fide error), and Pipiles v. Credit Bureau, Inc., 886 F.2d 22, 27 (2d Cir. 1989) (same), and Baker v. G.C. Servs. Corp., 677 F.2d 775, 779 (9th Cir. 1982) (same), and Johnson v. Eaton, 873 F. Supp. 1019, 1028 (N.D. La. 1995) (same), and Martinez v. Albuquerque Collection Servs., 867 F. Supp. 1495, 1502 (D.N.M. 1994) (same).

273. See Veillard v. Mednick, 24 F. Supp. 2d 863, 867 (N.D. Ill. 1998) (finding that the fact that the letter is on law firm letterhead is not enough to find a violation); Sturdevant v. Jolas, $942 \mathrm{~F}$. Supp. 426, 430 (D. Wis. 1996) (finding that it was not the intent of Congress to subject all attorneys who sent letters on their letterhead to an FDCPA action).

274. 363 F. Supp. 2d 345 (D. Conn. 2005). 
consumer about an important legal matter and indicated in its letter on law firm letterhead that its job was to collect a debt from the consumer. ${ }^{275}$ The collector also invited the consumer to call if he wanted to resolve the matter. ${ }^{276}$ The court read this language as indicating to the "'least sophisticated consumer"" that some type of legal action was in the offing, and that the consumer could stop it by paying off the debt. ${ }^{277}$ This language did not carry as strong an implication as that used by the debt collector in Bentley v. Great Lakes Collection Bureau, Inc., ${ }^{278}$ when the collector informed the consumer that it had instructions to "proceed with whatever legal means ... necessary to enforce collection." 279 The collector followed up with a second letter that indicated that the collector had to decide "what direction [had to] be taken to enforce collection." ${ }^{280}$ Although the debt collector in Bentley concluded its second letter with the statement that the collector had not taken, or was not taking, any action against the consumer, the court nevertheless held that the "least sophisticated consumer" would interpret the two letters in combination as saying that legal action was "likely and imminent." that a collector must be careful with its approach to a consumer if the statute of limitations is a problem, bearing in mind that courts will look for any veiled threat that accompanies the precatory language in the collector's letter. ${ }^{282}$

\section{THE VALIDATION NOTICE}

\section{A. The Details of the Debt}

A debt collector must give a consumer certain basic information about the debt either in its initial communication, or within five days thereafter. ${ }^{283}$ The statute identifies the amount of the debt as one of the

275. See id. at 347 (discussing the defendant's attempts to contact the plaintiff).

276. See id. (detailing the contents of the message the defendant left for the plantiff).

277. See id. at 355 (discussing the defendant's knowledge that the payment was due thirty days after the defendant received the collection letter).

278. 6 F.3d 60 (2d Cir. 1993).

279. Id. at 61 .

280. Id.

281. Id. at $61-62$

282. See id. at 62 (stating that the FDCPA prohibits a "threat" to take action that cannot ... [or] is not intended to be taken"); Pipiles v. Credit Bureau of Lockport, Inc., 886 F.2d 22, 25-26 (2d Cir. 1989) (same); Gervais, 363 F. Supp. 2d at 352 (stating that a collection notice that "makes the least sophisticated consumer uncertain as to her rights" violates the FDCPA).

283. See 15 U.S.C. $\S 1692$ g (2000) (listing the information that a collector must provide to the consumer). 
essential elements of the collector's disclosure statement, ${ }^{284}$ but the debt collector sometimes falls short of the requirement when it uses language that detracts from the main message about what the consumer owes. The debt collector promotes this confusion when it gives a figure that represents the outstanding principal, but then tries to make the consumer aware in some form or fashion that there are other charges that the consumer may have to pay which are not readily ascertainable at the time that the collector mails the collection letter to the consumer. Although the Seventh Circuit provided a model letter in Miller v. McCalla, Raymer, Padrick, Cobb, Nichols, \& Clark L.L.C. ${ }^{285}$ to guide debt collectors in the validation context, debt collectors have still found themselves in trouble by going beyond the Miller language to give the consumer other directives about the amount of the debt.

If the debt collector wants to recover not only the total amount due when it sends its collection letter, but also interest and other charges that accrue thereafter, the collector should add a Miller-type warning about additional amounts that may accrue between the date of the letter and the date of actual payment. ${ }^{286}$ Of course, if the debt collector is interested in recovering only the amount stated at the date of the letter, then it is less likely that the collector will run into difficulty if it merely states that amount without including any language about future charges.

The debt collector in Chuway v. National Action Financial Services, Inc. ${ }^{287}$ would have been safe if it had taken the Miller model more seriously. The debt collector identified the balance as $\$ 367.42$, but then asked the consumer to telephone for the "most current balance information." 288 It was evident that the debt collector wanted to collect more than the stated amount, but the consumer could not tell from the collector's letter what the additional amount would be. If the consumer had gleaned additional information from a telephone call to the debt collector, he might still have been in a quandary about what he should

284. See id. $\S 1692 \mathrm{~g}(\mathrm{a})(1)$ (requiring debt collectors to disclose the amount of debt).

285. 214 F.3d 872 (7th Cir. 2000). The Seventh Circuit offered a model letter to cover cases where the amount of the debt varies from day to day. See supra note 210 (citing Miller and providing the model letter).

286. In McDowall v. Leschack \& Grodensky, P.C., 279 F. Supp. 2d 197, 198 (S.D.N.Y. 2003), the collector stated the balance due was $\$ 2942.27$ plus interest and attorney's fees. The court concluded that "[b]y leaving an indeterminate amount of interest in the balance due, a collection letter leaves the least sophisticated consumer unsure of the magnitude of the debt." Id. at 200; see also Veach v. Sheeks, 316 F.3d 690, 693 (7th Cir. 2003) (holding that collection letter violated statute by including attorney's fees in principal balance because consumer is not liable for such fees before judgment by a court).

287. 362 F.3d 944 (7th Cir. 2004).

288. Id. at 947 . 
pay, and thus the validation notice would not have fulfilled its mission of informing the consumer about the amount of the debt. ${ }^{289}$ The important message that the debt collector must send in these circumstances is that it may have to make a later adjustment to the amount due because of "interest . . . and other charges that may vary from day to day." 290

It is open to question whether the "amount of the debt" refers to the unpaid balance, or to the amount that the debt collector seeks to recover at the time it sends its letter. In Olson v. Risk Management Alternatives, Inc. ${ }^{291}$ the debt collector listed $\$ 4881.81$ as the "Balance" and $\$ 1035.00$ as "Now Due." 292 The consumer complained that the debt collector had failed the $\S 1692 \mathrm{~g}(\mathrm{a})$ test by using two different amounts in the collection letter. The allegation was that the collector did not clearly disclose the amount of the debt. ${ }^{293}$

The court interpreted the "amount of the debt" under the statute as the "Balance" stated in the letter and the amount "Now Due" as the part of the balance that the debt collector was willing to accept until the next installment was due. ${ }^{294}$ It is questionable whether a debt collector should be given the flexibility to identify the amount of the debt in this way and to indicate the amount then due. The validation notice relates to the collector's communication in connection with the collection of any debt, and the collector is supposed to disclose the amount of that debt. The debt collector would hardly be trying to collect a sum that is not yet due, and so it seems that the amount of the debt to be disclosed must be the same as the amount that the collector is trying to collect. ${ }^{295}$ If there is no acceleration of the debt, the collector should not confuse matters by

289. The collector created an ambiguity by disclosing the balance as $\$ 367.42$ and then asking the consumer to call for the "most current balance information." The consumer would hardly know the "amount of the debt" by relying on the collection letter. See id. (detailing the contents of the collection letter sent to the plaintiff).

290. Miller, 214 F.3d at 876. The court's model letter leaves no doubt about the amount of the debt as of the date of the collection letter. See id. (providing a model letter for cases where the amount owed varies from day to day).

291. 366 F.3d 509 (7th Cir. 2004).

292. Id. at 510 .

293. See id. at 512 (stating plaintiff's argument that the "Now Due" language in the collection letter contradicted the validation notice and violated $\S 1692 \mathrm{~g}$ ).

294. Id. at 513.

295. It is true that a consumer should not interpret collection letters in a "bizarre or idiosyncratic fashion." Pettit v. Retrieval Masters Creditors Bureau, Inc., 211 F.3d 1057, 1060 (7th Cir. 2000). However, a collector must provide a validation notice in an effective and nonconfusing way. See Bartlett v. Heibl, 128 F.3d 497, 500 (7th Cir. 1997) (stating that debt collectors may not defeat the purpose of the FDCPA by disclosing information in a manner likely to confuse "unsophisticated debtors"); Swanson v. S. Or. Credit Servs., 869 F.2d 1222, 1225 (9th Cir. 1988) (stating that "if . . . the least sophisticated debtor would likely be misled by the notice . . . the credit service has violated the FDCPA"). 
listing different figures that do not meet the single disclosure of the amount of the debt. It is not within the spirit of the legislation to force a consumer to draw inferences from the collector's validation notice when the statute imposes a clear obligation on the collector to inform the consumer about the debt that it is trying to collect. The validation provision does not prevent a debt collector from itemizing the amount of the debt, but ultimately, the consumer must be able to understand the bottom line of the disclosure, the amount that the collector is trying to recover.

In Taylor v. Cavalry Investment, L.L.C. ${ }^{296}$ the collector identified the details of the debt as "PRINCIPAL BAL," "IINTEREST OWING,"” and "TOTAL BAL DUE.",297 The difficulty arose because the collector's letter contained additional language suggesting that the consumer might be responsible for interest, "if applicable." 298 This language was reminiscent of the Seventh Circuit's safe-harbor language in Miller, which drew the consumer's attention to the possibility that the amount due on the payment date might be greater because of interest and other charges. ${ }^{299}$ The court in Taylor saw nothing confusing about the debt collector's letter because it had carefully set out the total due, noting nevertheless that the consumer could be liable for additional charges in the interim. ${ }^{300}$ The language was not a model of clarity, but the court thought it was clear enough to prevent the consumer from raising a triable issue merely by asserting that he misunderstood the letter. ${ }^{301}$ Unlike other courts, the Seventh Circuit maintained that it was left to a consumer, on any but the clearest case, to present objective evidence of confusion through consumer surveys or similar evidence. ${ }^{302}$ The consumer was left holding the bag, defeated by the clarity of the letter.

Even when a letter is unclear on its face, a consumer may still have to present evidence of his own confusion if he hopes to get summary

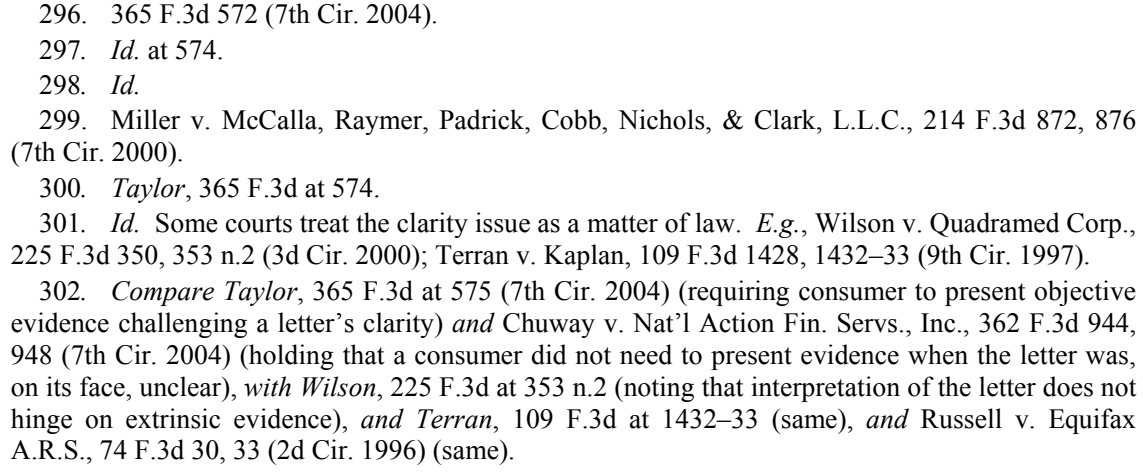

301. Id. Some courts treat the clarity issue as a matter of law. E.g., Wilson v. Quadramed Corp., 225 F.3d 350, 353 n.2 (3d Cir. 2000); Terran v. Kaplan, 109 F.3d 1428, 1432-33 (9th Cir. 1997).

302. Compare Taylor, 365 F.3d at 575 (7th Cir. 2004) (requiring consumer to present objective evidence challenging a letter's clarity) and Chuway v. Nat'l Action Fin. Servs., Inc., 362 F.3d 944, 948 (7th Cir. 2004) (holding that a consumer did not need to present evidence when the letter was, on its face, unclear), with Wilson, 225 F.3d at $353 \mathrm{n} .2$ (noting that interpretation of the letter does not hinge on extrinsic evidence), and Terran, 109 F.3d at 1432-33 (same), and Russell v. Equifax A.R.S., 74 F.3d 30, 33 (2d Cir. 1996) (same). 
judgment. In Croteau v. Dearing, ${ }^{303}$ the letter seemed unclear because although it stated that the consumer owed "\$8029.86 + interest," it nevertheless informed the consumer that the collector had been hired to collect $\$ 8029.86$, and that such an amount was past due. ${ }^{304}$ The collector urged the consumer to send a check for "the full amount." 305 It was unclear to the court whether or not the amount of the debt included interest, and if it did, there was no mention of a specific figure. ${ }^{306}$ Despite this problem, the consumer could not convince the court to grant her summary judgment on the issue because she had not submitted an affidavit to support evidence of her own confusion. ${ }^{307}$ There remained a material question that had to be answered.

\section{B. Conflicting Messages}

The validation notice has been the subject of continuing controversy. Despite the debt collector's obligation to disclose the salient elements of the transaction and the consumer's right to dispute the debt no later than five days after its initial communication with the consumer, ${ }^{308}$ there is nothing to prevent the debt collector from trying at the same time to collect the debt. ${ }^{309}$ This inevitable tension between the debt collector's disclosure obligation and its right to pursue the consumer has given rise to claims of contradiction and overshadowing by virtue of the language that debt collectors carefully craft to advance their own cause. The problem has caused such distress in the marketplace that the Seventh Circuit went out of its way in Bartlett v. Heibl ${ }^{310}$ to provide a model letter that provided some protection for debt collectors that were willing

\footnotetext{
303. No. 2:03 CV 257, 2005 U.S. Dist. LEXIS 1948 (N.D. Ind. Feb. 8, 2005).

304. Id. at $* 9 \_* 10$.

305. $I d$. at $* 3$.

306. Id. at *10

307. Id. Because the letter was unclear on its face, the consumer did not have to produce extrinsic evidence of confusion. Id. However, she still had to convince the court of her own confusion. Id.; see also Chuway, 362 F.3d at 948 (holding that a class representative's testimony as to her confusion created a triable issue of fact).

308. 15 U.S.C. $\S 1692 \mathrm{~g}(\mathrm{a})(2000)$.

309. See Peter v. GC Servs., L.P., 310 F.3d 344, 349-50 (5th Cir. 2002) (holding that collection letter demanding payment did not violate the FDCPA); Smith v. Computer Credit, Inc., 167 F.3d 1052, 1054-55 (6th Cir. 1999) (same); Terran v. Kaplan, 109 F.3d 1428, 1434 (9th Cir. 1997) (same); Advisory Opinion, supra note 23 ("[T]he thirty-day time frame . . . is a dispute period within which the consumer may insist the collector verify the debt, not a grace period within which collection efforts are prohibited."); 2005 FTC ANN. REP.: FAIR DEBT COLLECTION PRACTICES ACT 14, available at http://www.ftc.gov/reports/fdcpa05/050729fdcparpt.pdf (debt collectors may continue collection activities during the period that consumers may dispute).

310. 128 F.3d 497, 501-02 (7th Cir. 1997).
} 
to take advice. The safe-harbor letter should have solved many of the problems in the validation context, ${ }^{311}$ but problems remain simply because debt collectors cannot resist the urge to make sure that their message predominates in any communication with the consumer. ${ }^{312}$

In many cases, the debt collector runs into trouble by including unnecessary language in its collection letter. The collector is driven to excesses simply because it believes that such an approach will have a meaningful impact on the consumer. When a collector goes overboard with its message, it is very likely to run afoul of the statute. The collector in Sambor v. Omnia Credit Services, Inc. ${ }^{313}$ complied with the validation requirements, but then gave some advice about "suitable dispute documentation" that the consumer could use to dispute the debt. $^{314}$ The collector must have thought that it was being helpful by volunteering this information. ${ }^{315}$ The only problem was that a consumer could reasonably conclude that he could dispute the debt only if he had that documentation. But the statute does not require the consumer to have any documentation to lodge his dispute. Therefore, when the collector thought that it was benefiting the consumer with its examples of "suitable dispute documentation," it was actually misleading the consumer into thinking of a documentary requirement, ${ }^{316}$ when in fact the consumer only had to state that he disputed the debt. ${ }^{317}$ The collector

311. The Bartlett court's objective was "to devise a form of words that [would] inform the debtor of the risk of his being sued without detracting from the statement of his statutory rights." Id. at 501. The model letter gave the usual details of the debt and the validation notice, but it also warned the debtor that the law did not require the collector to wait until the end of the thirty-day dispute period before suing to collect the debt. Id. at 502 .

312. See DeSantis v. Computer Credit, Inc., 269 F.3d 159, 162 (2d Cir. 2001) (consumer stated actionable claim that collection letter was confusing and contradictory when it insisted on valid reason for nonpayment in light of the validation notice); United States v. Nat'l Fin. Servs., Inc., 98 F.3d 131, 137 (4th Cir. 1996) (ten-day payment deadline contradicted thirty-day period in validation notice for disputing debt); Graziano v. Harrison, 950 F.2d 107, 111 (3d Cir. 1991) (threat of immediate legal action if payment not made within ten days would induce consumer to overlook statutory right to dispute debt within thirty days); Swanson v. S. Or. Credit Servs., Inc., 869 F.2d 1222, 1225 (9th Cir. 1989) (finding that threat to consumer's credit rating if debt not paid in ten days contradicted, and collection language overshadowed, validation notice); Adams v. Law Offices of Stuckert \& Yates, 926 F. Supp. 521, 527 (E.D. Penn. 1996) (holding that demand for immediate payment contradicted validation notice).

313. 183 F. Supp. 2d 1234 (D. Haw. 2002).

314. Id. at 1235 .

315. See id. at 1240 (citing Castro v. ARS Nat'l Servs., Inc., 2000 WL 264310, at *3 (S.D.N.Y. 2000) (stating that the "additional language may have been intended to aid debtors").

316. The collector's use of the adjective "suitable" suggested that certain documentation would be "unsuitable." Id. (citing Castro, 2000 WL 264310, at*3). But the point is that the statute does not require a consumer to submit any documentation at all to the collector if he wants to dispute the debt. Id.; see also Castro, 2000 WL 264310, at *3 (stating that "[s]ection 1692g(a)(3) does not require debtors to provide documentation").

317. See 15 U.S.C. $§ 1692 \mathrm{~g}(\mathrm{a})(3)-(4)$ (2000) (containing no reference to documentation). 
may have left the consumer with the impression that there was "unsuitable" documentation that would not fit the bill.

When the collector used additional language in Franzos v. Pinnacle Credit Services $L L C,{ }^{318}$ it managed to get a judgment on the pleadings because the language merely indicated how the consumer could support his claim that the debt listed with the collector was in error and did not overshadow the validation notice. ${ }^{319}$ There was no reference in Franzos to "suitable documentation" for disputing the debt, ${ }^{320}$ and the debt collector gave a clear statement in the body of the letter of the consumer's right to seek verification of the debt. The other language appeared in a box at the end of the letter, thus giving no impression that the consumer's right to dispute the debt was subject to any contingency. ${ }^{321}$

In Sambor, the "suitable documentation" language appeared immediately after the validation notice, thus suggesting that there was a link between the two. ${ }^{322}$ The collector in Franzos did not make that mistake, for not only did it make a point of separating the additional language from the all-important validation notice, but it also set it out in smaller type as if to make its point that satisfactory proof about any listing error was incidental to the validation notice. ${ }^{323}$ There was less doubt in Franzos than in Sambor about the purpose of the language. Nevertheless, one still wonders whether the collectors in Sambor and Franzos could have done a better job of explaining how the validation notice fit in with the rest of the collection letter. After all, a consumer should not be left to ponder whether he can merely say that he disputes the debt and leave it at that, or whether he must support his dispute with

\footnotetext{
318. 332 F. Supp. 2 d 682 (S.D.N.Y. 2004).

319. The additional language in the collection letter read as follows:

You may already have satisfactory proof that this account is listed with us in error. If so, please send this notice back along with a copy of one of the following to support your claim:

Bankruptcy Notice from the court stating case number and filing date

Certificate of Death

Canceled check showing settlement in full

Letter from original lending institution clearing your account. Id. at 684 .

320. Compare Franzos, 332 F. Supp. 2d at 684, with Sambor, 183 F. Supp. at 1239-40.

321. Franzos, 332 F. Supp. 2d at 687. The additional language in the collection letter was placed in smaller print in a box at the end of the collection language. $I d$.

322. See Sambor, 183 F. Supp. 2d at 1239-40 (stating that the crux of the problem was the location of the "suitable dispute documentation" immediately after the notification of rights).

323. See Franzos, 332 F. Supp. $2 d$ at 687 (stating that "the format of the Letter is such that even the least sophisticated consumer would not be confused").
} 
evidence satisfactory to the collector. ${ }^{324}$ Although the court in Franzos was satisfied that the debt collector had merely brought to the consumer's attention some reasons why the debt might no longer be valid, the overriding consideration was the fact that the collector did not make the consumer's right of verification dependent upon the production of any of the documents mentioned in the collection letter. ${ }^{325}$

Some debt collectors seem to go out of their way to create ambiguity in their collection language. Sometimes a collector gets away with the ambiguity, but not because it deserves to do so. In McStay v. I.C. System, Inc. ${ }^{326}$ the collector had dutifully followed the law in terms of the validation notice, ${ }^{327}$ but nevertheless advised the consumer that it would report the consumer to the National Credit Reporting Agencies if the account remained unpaid after thirty days. ${ }^{328}$ The consumer thought this reference to "thirty days" was sufficiently confusing to violate the FDCPA because it did not say when the thirty-day period would begin to run. $^{329}$ A consumer could have interpreted the dispute period to run either from the date of the letter or from the date of its receipt. ${ }^{330}$ Nevertheless, the court looked at the collection effort as a whole and found no cause for alarm because of the statutorily correct validation language, which pinpointed the time for disputing the debt as "within 30 days after receiving [the] notice." 331 This was a problem of the

324. In the same way that the Bartlett court's model letter emphasized that a collector does not have to wait until the end of the thirty-day dispute period before suing, Bartlett v. Heibl, 128 F.3d 497, 502 (7th Cir. 1997), the collector in a Franzos-type case can include language that reassures the consumer that although the statute does not require the consumer to submit any documentation when he disputes the debt, he may do so if he wants to. See Franzos, 332 F. Supp. 2d at 686 (finding a written response sufficient without further documentation). In this way, a collector leaves no doubt about the consumer's statutory right to dispute the debt without undertaking any obligation to comply with other nonexistent statutory requirements. See Mendez v. M.R.S. Assocs., No. 03-C6753, 2005 WL 1564977, at *5 (N.D. Ill. June 27, 2005) (finding collector's requirement of providing a valid reason for disputing the debt to be a violation of FDCPA); Whitten v. ARS Nat'1 Servs., Inc., No. 00-C-6080, 2002 WL 1332001, at *5 (N.D. Ill. June 18, 2002) (finding collector's requirement of providing documentation to dispute debt to be violation of FDCPA); NAT'L CONSUMER LAW CTR., supra note 33, $§ 5.7 .2 .6 .1$, at 223 ("[A] consumer need only send a letter stating 'I dispute the debt' in order to dispute the debt.").

325. See Franzos, 332 F. Supp. 2d at 686 (finding a list of documents contained in letter to be a suggestion, not a requirement for disputing the debt).

326. 308 F.3d 188 (2d Cir. 2002)

327. Id. at $189-90$.

328. Id. at 189

329. Id. at 190

330. Id.

331. Id. at 191. This language contrasted sharply with the collector's threat to report the consumer to the credit reporting agencies if "after 30 days [the] account is not paid in full." Id. at 189. 
collector's own doing. ${ }^{332}$ The reference to "after 30 days" was sure to raise a question in the consumer's mind, even if it would not baffle the consumer within the context of the whole letter. This is but one example of the kind of problem raised by a collector's loose language. The collector carefully followed the statutory mandate by using the precise language of $\S 1692 \mathrm{~g}$ and then confused matters with its own message. ${ }^{333}$

This is not an unusual predicament for a debt collector. A similar problem arose recently in Vega v. Credit Bureau Enterprises ${ }^{334}$ when the collector's validation notice passed muster, but its other collection language left much to be desired. ${ }^{335}$ The first sentence of the collection letter advised: "This account has been forwarded to this office... to collect the balance in full unless disputed in writing within 30 days from this notice." ${ }^{336}$ The collector obviously wanted to make an immediate impression on the consumer that the consumer had to dispute the debt in writing or the collector would try to collect the balance. This was the entire message in the letter's first paragraph. ${ }^{337}$ There was no ambiguity in the language. The collector was confident in requiring the consumer's dispute to be in writing because it believed that Congress intended $\S$ $1692 \mathrm{~g}(\mathrm{a})(3)$ to have that requirement, just like $\S 1692 \mathrm{~g}(\mathrm{a})(4)$ and $\S$ $1692 \mathrm{~g}(\mathrm{a})(5) .^{338}$ This was by no means a novel defense, for collectors have tried on many occasions to convince a court that a writing requirement should be implied in subsection (a)(3) just because it appears in both subsections (a)(4) and (a)(5). Fortunately, most courts

332. The language concerning the reporting of the consumer's status after thirty days appeared on the front of the collection letter. Id. at 189. At the bottom there was a reference in capitals to the reverse side of the letter for important information. Id. That important information was the validation notice which correctly identified the dispute period as thirty days after receiving the collection notice. Id. Although the court was sympathetic with the collector on this occasion, the question still remains whether a consumer should have to work out the conflict for himself or whether a collector should be forced into a consistent pattern of fulfilling the statutory mandate without confusing the consumer. It is not asking too much to require the collector to convey its message clearly and effectively without creating uncertainty in the consumer's mind. See Savino v. Computer Credit, Inc., 164 F.3d 81, 86 (2d Cir. 1998) (stating that changing language in the demand letter will avoid confusion without imposing a burden on collector); Bartlett v. Heibl, 128 F.3d 497, 500-01 (7th Cir. 1997) (finding failure to explain apparent contradiction violated the FDCPA); Miller v. Payco-Gen. Am. Credits, Inc., 943 F.2d 482, 484 (4th Cir. 1991) (holding that technical compliance is not sufficient if notice is not effectively conveyed); Edwards v. Nat'l Bus. Factors, Inc., 897 F. Supp. 455, 458 (D. Nev. 1995) (finding notice with confusing language to be invalid).

333. See McStay, 308 F.3d at 191 ("[T]he letter contained all the information specifically required by section $1692 \mathrm{~g}$ [, however,] . . . the message on the front of the letter is ambiguous.").

334. No. CIVA02CV1550DGT KAM, 2005 WL 711657 (E.D.N.Y. Mar. 29, 2005)

335. Id. at $* 7, * 10$.

336. Id. at *1.

337. Id.

338. Id. at $* 7$. 
have not read a writing requirement into subsection (a)(3) because they have seen the rationale for the statutory distinction between the subsections and have clung to the plain meaning of the statute. ${ }^{339}$ Subsection (a)(3) allows a consumer to raise questions about the debt without committing his objections to writing so that a collector would at least be aware of possible problems concerning the debt. ${ }^{340}$ This does not detract from the requirement that the notice of the dispute be in writing if the consumer wants to invoke his verification rights under the statute. $^{341}$ If the consumer disputes the debt in writing, the debt collector must suspend its collection activities until it complies with the consumer's request for verification. ${ }^{342}$ Therefore, subsections (a)(3) and (a)(4) fulfill different functions. ${ }^{343}$

339. See Camacho v. Bridgeport Fin. Inc., 430 F.3d 1078, 1080 (9th Cir. 2005) (finding no writing requirement under $\S 1692 \mathrm{~g}(\mathrm{a})(3))$; Baez v. Wagner \& Hunt, 442 F. Supp. 2d 1273, 1277 (S.D. Fla. 2006) (finding that Congress intentionally omitted a writing requirement from $\S$ 1692g(a)(3)); Rosado v. Taylor, 324 F. Supp. 2d 917, 929 (N.D. Ind. 2004) (imposing a writing requirement in $\S 1692 \mathrm{~g}(\mathrm{a})(3)$ violates the statute); In re Risk Mgmt. Alternatives, Inc., 208 F.R.D. 493, 502 (S.D.N.Y. 2002) (" $[$ T] he Second Circuit . . . would permit disputes to be raised otherwise than in writing."); Sanchez v. Robert E. Weiss, Inc. (In re Sanchez), 173 F. Supp. 2d 1029, 1035 (N.D. Cal. 2001) (finding no writing requirement under $\S 1692(a)(3)$ ); Ong v. Am. Collections Enter., No. 98-CV-5117 (JG), 1999 WL 51816, at *2 (E.D.N.Y. Jan. 15, 1999) (reasoning that Congress's omission of "in writing" from $\S 1692(a)(3)$ was intentional). But see Graziano v. Harrison, 950 F.2d 107, 112 (3d Cir. 1991) (finding § 1692(a)(3)-(5) to have a writing requirement); Castillo v. Carter, No. IP-99-1757-C H/G, 2001 WL 238121, at *4 (S.D. Ind. Feb. 28, 2001) (finding no violation of $\S 1692 \mathrm{~g}(\mathrm{a})(3)$ when collector required dispute in writing); Sturdevant v. Thomas E. Jolas, P.C., 942 F. Supp. 426, 429 (W.D. Wis. 1996) (requiring dispute of debt in writing because court was persuaded by Graziano).

340. See 15 U.S.C. $§ 1692 \mathrm{~g}(\mathrm{a})(3)$ (2000) (requiring the debt collector to give the consumer a written statement that the debt will be assumed to be valid unless the consumer disputes the validity of the debt).

341. The phrase "in writing" appears in $\S 1692 \mathrm{~g}(\mathrm{a})(4)$, but not in $\S 1692 \mathrm{~g}(\mathrm{a})(3)$.

342. 15 U.S.C. $\S 1692 \mathrm{~g}(\mathrm{~b})$.

343. In Graziano, the Third Circuit was worried that if it did not require a writing in both $\S$ $1692 \mathrm{~g}(\mathrm{a})(3)$ and $\S 1692 \mathrm{~g}(\mathrm{a})(4)$, "the debt collector would be without any statutory ground for assuming that the debt was valid, but nevertheless would not be required to verify the debt ... and would be permitted to continue debt collection efforts." 950 F.2d at 112 . It saw no reason why Congress would create such an "incoherent ... system." Id. Another court thought this was a "silly result" and hoped that this was not what Congress intended. In re Risk Mgmt. Alternatives, 208 F.R.D. at 502. Nevertheless, the court in Sanchez provided a reasonable explanation for reading $\S$ $1692 \mathrm{~g}(\mathrm{a})(3)$ as not requiring a writing. It suggested as follows:

This reading of $\S 1692 \mathrm{~g}(\mathrm{a})(3)$ would serve two purposes: 1) It would provide an informal red flag to a debt collector so that it might quickly and inexpensively check the validity of the debt without triggering the formal requirements of $\S \S 1692 \mathrm{~g}(\mathrm{a})(4)$, (5) and $1692 \mathrm{~g}(\mathrm{~b})$; and 2) it would provide limited protection to debtors upon communicating a non-written dispute.

173 F. Supp. 2d at 1034.

In Graziano, the Third Circuit did not discuss the presumption that when Congress omits particular language in one section but includes it in another section of the same statute, it acts intentionally to create a distinction between the two sections. See Gozlon-Peretz v. United States, 498 U.S. 395, 404 (1991) (discussing the implication of omission of certain language by Congress). 
When the collector in Vega used the first paragraph of its letter to emphasize the necessity of disputing the debt in writing, the subsequent validation language at the bottom of the collection letter paled in comparison to the initial message. It was not the only misleading part of the letter. Here was another example where a collector went out of its way to contradict the clear language of the validation notice by requiring the consumer to dispute the debt "within 30 days from [the] notice." 344 When the consumer looked at the concluding paragraph, she saw that she could dispute the debt "within thirty (30) days from receiving [the] notice." "345 One could not find a clearer contradiction. Surely the collector could not contend that those two phrases had the same meaning, but there they were in the same letter, crying out for an explanation.

Although a collector does not have to quote the exact statutory language in its validation notice, it must be careful not to wander too far afield in trying to comply with the statute. When the collector in Smith $v$. Hecker $^{346}$ advised the consumer that the debt would be "assessed valid" if the consumer did not dispute it, ${ }^{347}$ he was sure to raise questions about his reasons for replacing the language, "assumed to be valid," with his version. It seemed odd that the collector would go out of his way to change "assumed" to "assessed," when the new term seemed destined to cause problems for him. The court looked to the definition of the two words and concluded that a consumer would be unlikely to interpret the sentence containing the word "assessed" to mean that her debt would be assumed valid if she did not dispute it. ${ }^{348}$ The term "assessed" gave the impression that the collector was referring to a determination of the debt's validity by some external authority or credit reporting agency. ${ }^{349}$

But that was not the only cause of confusion. The statutory language makes it clear that if the consumer does not dispute the debt, the debt will be assumed to be valid by the debt collector. Not only did the debt

There is something to be said for respecting the plain language of the statute. See 2A SINGER, supra note $41, \S 46.01$ (discussing the "plain meaning rule" of statutory construction); see also Camacho, 430 F.3d at 1081 (stating that "[ $\mathrm{t}]$ he plain meaning of $\S 1692 \mathrm{~g}$ is that debtors can trigger the rights under subsection (a)(3) by either an oral or written "dispute"); Brady v. Credit Recovery Co., 160 F.3d 64, 66-67 (1st Cir. 1998) (using "plain language" to interpret $§ \S 1692 \mathrm{e}(8)$ and 1692g(b)); Vega, 2005 WL 711657, at*8 (discussing use of plain language rule to determine the effect of omitting the writing requirement); Walters v. PDI Mgmt. Servs., No. 1:02-CV-1100-JDT-TAB, 2004 WL 1622217 , at *5 (S.D. Ind. Apr. 16, 2004) (finding that "[t]he plain language of subsection (a)(3) does not require that the consumer dispute the validity of the debt in writing").

344. Vega, 2005 WL 711657 , at*1.

345. Id. (emphasis added).

346. No. Civ.A. 04-5820, 2005 WL 894812 (E.D. Pa. Apr. 18, 2005).

347. Id. at $* 1$.

348. Id. at $* 5$.

349. Id. 
collector in Smith substitute "assessed" for "assumed," but he also omitted "by the debt collector" from his version of the validation notice. ${ }^{350}$ Therefore, the consumer did not know who was doing the "assessing" under the collector's scheme of things. This omission fit in nicely with the use of the term "assessed" to prove deception, thus contributing to an ineffective validation notice. A consumer might have been led to believe that unless she disputed the debt, the debt would be regarded as valid by a "court, credit agency, or other entity rather than merely by the debt collector." 351 The collector could hardly expect much sympathy from the court under these circumstances, since he gave no rationale for deviating from the statutory message.

A consumer has a right to seek verification of the debt within thirty days after receiving the validation notice from the debt collector, and until the consumer does so, the debt collector can continue its collection activities during this thirty-day window simply because it is not a grace period for the consumer's respite. ${ }^{352}$ It is instead a period during which a consumer may contest the debt's validity, and if he does so, the debt collector must then cease collection of the debt until it can mail the verification to the consumer. ${ }^{353}$ Even though the debt collector must cease collection when the consumer lodges his dispute, it does not have to inform the consumer of this requirement. ${ }^{354}$ If it is important for a consumer to be aware of the tools in his armor, then the drafters should have left no stone unturned in outlining the mechanism for the consumer to challenge the debt collector. ${ }^{355}$ Once the consumer knows that he will have some temporary relief from the debt collector's bombardment, he will probably be more enthusiastic about marshalling his forces to deal

350. The statute requires the debt collector to give the consumer a statement that if the consumer does not dispute the debt, "the debt will be assumed to be valid by the debt collector." 15 U.S.C. \& 1692g(a)(3) (2000). The collector's message was that "[t]he debt will be assessed valid." Smith, 2005 WL 894812 , at $* 1$.

351. Id. at $* 5$.

352. See Smith v. Computer Credit, Inc., 167 F.3d 1052, 1055 (6th Cir. 1999) (discussing collection agency's ability to continue collection during thirty day period); Bartlett v. Heibl, 128 F.3d 497, 501 (7th Cir. 1997) (same); Advisory Opinion, supra note 23 (same); 2005 FTC ANN. REP., supra note 309, at 14 ("The Commission consistently has taken the position that the existing statute permits collection efforts to continue during the thirty-day period if the consumer has not disputed the debt in writing or requested verification." (citation omitted)).

353. 15 U.S.C. $\S 1692 \mathrm{~g}(\mathrm{~b})$

354. NAT'L CONSUMER LAW CTR., supra note 33, §5.7.3.4, at 239. The court in Bartlett was generous by including that requirement in its model validation notice. See 128 F.3d at 502 (stating the court's suggested form and including a clause informing the debtor of the requirement).

355. It seems that $\S 1692 \mathrm{~g}(\mathrm{~b})$ is a natural corollary of $\S 1692 \mathrm{~g}(\mathrm{a})(4)$. A consumer would certainly be interested in knowing the effect of querying the validity of the debt. It is not clear why the drafters isolated, in $\S 1692 \mathrm{~g}$, the effect that a consumer's action would have on the debt collector. 
with the debt collector. The interim cease-fire period will surely create the right climate for a resolution of the problem.

\section{The Impact of the Validation Language}

Although the statute gives a consumer thirty days to dispute the debt, he may find himself in difficulty if the debt collector continues the collection process by placing a lien on the consumer's property. In Shimek v. Forbes, ${ }^{356}$ the debt collector mailed a lien to the county clerk on the same day that it sent a demand letter to the consumer advising the consumer that he had a right to dispute the debt within thirty days. ${ }^{357}$ When the consumer later requested verification, the debt collector did nothing to prevent the county clerk from recording the lien. ${ }^{358}$ The consumer raised the question whether the statutory directive for the collector to cease its collection activities pending verification of the debt included an affirmative obligation to intervene and stop the recording of the lien. ${ }^{359}$ The Eleventh Circuit did not read any such obligation into the statute, for the debt collector had already mailed the documents to the county clerk when the consumer disputed the debt. ${ }^{360}$ The collector would have violated the statute if it had done its mailing after the consumer had lodged his dispute. ${ }^{361}$

The Shimek case provides an example of the kind of mischief that the validation section can cause as long as the FDCPA recognizes the thirtyday period as merely one that gives the consumer an opportunity to query the debt, without imposing a corresponding duty on the debt collector to suspend its activities in the absence of that query. ${ }^{362}$ Even though a consumer has the right to seek verification, that does not necessarily

\footnotetext{
356. 374 F.3d 1011 (11th Cir. 2004).

357. Id. at 1012.

358. See id. at 1012-13 (showing lack of action on part of debt collector leading to the lien being recorded)

359. Id. at 1014 .

360. Id.

361. See Smith v. Transworld Sys., Inc., 953 F.2d 1025, 1031 (6th Cir. 1992) (holding that second letter mailed after debtor's cease-and-desist letter was a bona fide error); Loigman v. Kings Landing Condo. Ass'n, 734 A.2d 367, 373 (N.J. Super. Ct. Ch. Div. 1999) (holding that repeated attempts to collect debt after verification letter was sent violated the FDCPA).

362. See Smith v. Computer Credit, Inc., 167 F.3d 1052, 1055 (6th Cir. 1999) (debt collector's letter did not threaten debtor's right to question validity of debt); Bartlett v. Heibl, 128 F.3d 497, 501 (7th Cir. 1997) (explaining that the debt collector must cease collection activities after the mailing of a verification letter); Miller v. Payco-Gen. Am. Credits, Inc., 943 F.2d 482, 484 (4th Cir. 1991) (cessation of debt collection activities only until validation letter is sent); Advisory Opionion, supra note 23 (discussing the FTC's opinion that collectors need not cease collection efforts during the thirty-day period if debtor does not dispute the debt in writing).
} 
mean that he will get it. A debt collector may adopt a strategy of returning all disputed debts to the creditor. Although the debt collector will be unable to resume its activities until it validates the debt, it may nevertheless ignore the consumer's request for verification and leave the creditor to deal with the problem. Once that happens, the debt collector is out of the picture and thereafter has no obligation to respond to the consumer's request for verification despite its promise to do so. ${ }^{363}$

It seems odd that the debt collector can keep the consumer in limbo without giving him the results of its inquiries concerning the validity of the debt. The statute allows the debt collector to give a promise of verification, but does not require the debt collector to tell the consumer that it is suspending collection while it verifies the debt. ${ }^{364}$ If the creditor has an arrangement with the debt collector to return the files of all disputed debts, the debt collector really has a safety valve for all disputes. The parties' agreement relieves the collector of any duty to respond to the consumer's dispute, while at the same time allowing the creditor to try again through another collector. The statute would surely be more effective if it required the debt collector to advise the consumer that it will either furnish the requested verification or cease collection activities. ${ }^{365}$ In the latter event, the debt collector should promptly notify the consumer of its decision so that the consumer does not think that he has a cloud hanging over him, even though the debt collector may not be pressing him at the moment. This approach would be more satisfactory than merely allowing a collection agency to choose between ceasing all collection activity or providing verification.

The statute also requires the debt collector to include in its validation notice a statement that it will obtain "verification of the debt or a copy of a judgment against the consumer." 366 In all fairness, the collector has no choice in making this promise, since the statute demands that the

363. See Jang v. A.M. Miller \& Assocs., 122 F.3d 480, 484 (7th Cir. 1997) (holding that a debt collector may choose not to verify the debt if it ceases collection activity); Smith, 953 F.2d at 1032 (holding that debt collector did not violate $\S 1692 \mathrm{~g}(\mathrm{~b})$ since it ceased collection activities); Bleich v. Revenue Maximization Group, Inc., 233 F. Supp. 2d 496, 500 (E.D.N.Y. 2002) (explaining that once debtor attempts verification all collection activity must stop); Sambor v. Omnia Credit Servs., Inc., 183 F. Supp. 2d 1234, 1242 (D. Haw. 2002) (holding that because debt collector ceased collection activities verification was not required under FDCPA).

364. See 15 U.S.C. $\S 1692 \mathrm{~g}(\mathrm{~b})$ (2000) ("[D]ebt collector shall cease collection of the debt ... until the debt collector obtains verification of the debt or a copy of the judgment ....").

365. Even though the court in Jang ruled in favor of the collector, it recognized that "the statute might be more informative for debtors if it required a notice that the debt collector would either provide the requested verification or cease all collection activities." 122 F.3d at 484.

366. 15 U.S.C. $\S 1692 \mathrm{~g}(\mathrm{~b})$ 
collector's notice include a statement to that effect. ${ }^{367}$ Nevertheless, there is room for improvement in this context because there may be no existing judgment against the consumer, and the debt collector may find itself promising to produce a copy of something that does not exist. The use of the term "judgment" is sufficient to send a consumer into a panic because a consumer may not expect a debt collector to refer to a judgment where none exists. It is submitted, therefore, that the validation notice should add such language as is necessary to clarify the point that the debt collector will obtain a copy of a judgment only if one has been obtained against the consumer. ${ }^{368}$ Such an amendment would not dilute the effect of the debt collector's promise, but instead would make its fulfillment depend on the actual state of affairs. ${ }^{369}$ It may even be desirable for a collector to omit any reference to a judgment in its validation notice if there is no judgment. ${ }^{370}$ A reference in this context to "a non-existent judgment serves no similar salutary purpose," especially if a collector has promised a copy of the judgment rather than one of $a$ judgment. ${ }^{371}$ Such specificity leads to greater mischief, for then the consumer is led to believe that the collector is dealing with a judgment that has already been obtained. This only adds to the consumer's confusion.

367. See Moore v. Ingram \& Assocs., 805 F. Supp. 7,9 (D.S.C. 1992) (holding that the required notice provision is not misleading); Check Cent. of Or., Inc. v. Barr (In re Barr), 54 B.R. 922, 925 26 (D. Or. 1984) (noting that the language of the letter mirrors FDCPA); Blackwell v. Prof'1 Bus. Servs. of Ga., Inc., 526 F. Supp. 535, 539 (N.D. Ga. 1981) (holding that use of the term "judgment" in notice does not violate FDCPA); Duncan v. Nichols, 451 S.E.2d 24, 26 (S.C. Ct. App. 1994) (allowing language directly taken from $\S 1692 \mathrm{~g}(\mathrm{a})(4)$ to be used in notice letter).

368. The cases have had no problem with a collector's use of the statutory language because the validation notice contains the collector's promise to obtain verification of the debt or a copy of a judgment. Thus, the courts interpret that language as providing an alternative for the collector. In the absence of a judgment, it can always rely on the verification to support its demands. Moore, 805 F. Supp. at 9; In re Barr, 54 B.R. at 925-26.

369. Although the statutory language refers to "a copy of a judgment," $\$ 1692 \mathrm{~g}(\mathrm{a})(4)$, it may be problematic if the collector refers instead to "a copy of the judgment." This language suggests that a judgment has been obtained against the consumer and a collection letter does not avoid the confusion even if it also promises verification of the debt as an alternative. The court in Blackwell, applying a reasonable consumer standard, did not appreciate the distinction between "a judgment" and "the judgment" and found that "a verification notice differing by a single definite article from the language of the statute [did] not in itself constitute a false representation of the legal status of the debt." 526 F. Supp. at 539.

370. See Beeman v. Lacy, Katzen, Ryen \& Mittleman, 892 F. Supp. 405, 410 (N.D.N.Y. 1995) (holding that a debt collector should not confuse a debtor if a judgment does not exist); Stojanovski v. Strobl \& Manoogian, P.C., 783 F. Supp. 319, 324 (E.D. Mich. 1992) (explaining that it would be a violation to falsely state that a copy of a nonexistent judgment would be produced).

371. Beeman, 892 F. Supp. at 410. 


\section{The Relevance of a Writing}

On another front, one may query the rationale for allowing a debt collector to satisfy $\S 1692 \mathrm{~g}$ with an oral validation notice. ${ }^{372}$ The statute allows a debt collector to convey the $\S 1692 \mathrm{~g}$ information in its initial communication with the consumer, but such a communication need not be written. ${ }^{373}$ It is only if the debt collector does not use the initial communication to give the validation notice that the statute requires a written notice within five days thereafter. ${ }^{374}$ A consumer should not be expected to absorb all of the information contained in an oral notice, but the statute imposes no writing requirement for the initial contact.

The case for allowing a debt collector to give a consumer oral notice of the consumer's validation rights under the current statutory language is based on the placement of the phrase "the following information" in $\S$ $1692 \mathrm{~g}(\mathrm{a})$. The present language requires the debt collector to give the consumer a written notice containing the information in $\S 1692 \mathrm{~g}(\mathrm{a})(1)-$ (5), unless the collector includes that information in the initial communication. ${ }^{375}$ The only way of interpreting the section as mandating a writing in this context is to conclude that the phrase "the following information" refers to the "written notice" required of the debt collector. ${ }^{376}$ But it seems more logical to treat the written notice as containing the information contemplated by the statute, rather than regarding the notice itself as the information.

The only other approach that will support a writing in all circumstances covering a validation notice is if the definition of "communication" is restricted to a writing. ${ }^{377}$ The legislative history

372. The FTC Staff Commentary provides that "[i]f a debt collector's first communication with the consumer is oral, he may make the disclosures orally at that time in which case he need not send a written notice." FTC Staff Commentary, supra note 11, at 50,108.

373. The statute defines the term "communication" as "the conveying of information regarding a debt directly or indirectly to any person through any medium.” 15 U.S.C. $\S 1692 \mathrm{a}(2)$ (2000).

374. 15 U.S.C. $§ 1692 \mathrm{~g}(\mathrm{a})$.

375. It is more reasonable to read the section as requiring the debt collector to send the consumer a written notice containing certain information, unless that information is contained in the initial communication. The information contemplated is set out in $\S 1692 \mathrm{~g}(\mathrm{a})(1)-(5)$.

376. It seems contrary to the plain language of the statute to equate "information" with the required "notice." It is the notice that contains the information.

377. The definition of "communication" is clear and does not support restricting it to a writing. See $\S 1692$ a(2) (defining "communication" as the conveying of information regarding a debt directly or indirectly to any person through any medium). The FTC Commentary agrees that "the definition includes oral and written transmission of messages which refer to a debt." FTC Staff Commentary, supra note 11, at 50,101; see also Silbert v. Asset Res., Inc., No. 99-1348, 2000 WL 680243, at *2 (D. Minn. Feb. 14, 2000) (initial phone call would be valid notice if $\S 1692 \mathrm{~g}(\mathrm{a})$ disclosures were provided) 
does not offer any independent evidence to require such a writing. A prior Senate bill demanded that the debt collector should, "unless such is contained in the initial communication[,] . . . send the consumer a written notice containing the following information." ${ }^{378}$ Even in this context, the word "such" refers to the "information" that the notice must contain, rather than to the notice itself, for one would not normally think of a written notice being contained in a communication. The notice is itself the communication, and the language in both the bill and the current statute suggests that it is the initial communication or the subsequent written notice that must contain the information that is the essence of the consumer's verification rights. ${ }^{379}$

The validation section raises another issue concerning the effect of a consumer disputing the debt. Under subsection (a)(3), a collector will assume that the debt is valid if the consumer does not dispute the debt within thirty days, and under subsection (a)(4), the debt collector promises to obtain verification if the consumer disputes the debt in writing. The judicial disagreement that has arisen from the absence in subsection (a)(3) of the phrase "in writing," has left some uncertainty about the congressional intent in drafting these subsections. It is reasonable to infer that Congress intended to provide some leeway for a consumer to lodge some objection to the debt collector's claim without going through the formality of a writing, especially if the consumer is unable to fulfill the writing requirement. ${ }^{380}$ If the consumer disputes the debt orally, the debt collector may be motivated to investigate the transaction in order to satisfy itself of the validity of the debt. Allowing the consumer to dispute the debt orally may still serve some legitimate purpose by avoiding litigation costs. ${ }^{381}$

378. S. 918, 95th Cong. $\S 809$ (a) (1977).

379. The Senate Report on the FDCPA does not do much to support the idea that the statute forbids an oral validation notice. For example, in explaining the validation of debt, the report provides that "[a]fter initially contacting a consumer, a debt collector must send him or her written notice stating the name of the creditor and the amount owed." S. Rep. No. 95-382, at 4 (1977), reprinted in 1977 U.S.C.C.A.N. 1695, 1699. This does not suggest that the initial contact must be in writing and the statute requires the written notice only if the "information" is not contained in the "initial communication." 15 U.S.C. $§ 1692 \mathrm{~g}(\mathrm{a})$. It is understandable that the drafters wanted to ease the burden on a collector by not requiring it to give the validation notice again if it had already done so in the first communication. See NAT'L CONSUMER LAW CTR., supra note 33, § 5.7.2.4, at 216 (explaining why statutory language should be interpreted to require written notice of verification rights). However, it is fair to say that the drafters have fallen short because of their failure to deal with the impact of the term "communication" on the overall validation scheme.

380. See Ong v. Am. Collections Enter., Inc., No. 98-CV-5117, 1999 WL 51816, at*3 (E.D.N.Y. Jan. 15, 1999) ("It is not unreasonable to believe that some consumers who wish to dispute an alleged debt may lack the ability or wherewithal to do so in writing ....").

381. A debt collector would hardly want to pursue a consumer without further inquiry if there is any inkling that the validity of the debt is in question. As the court in Spearman v. Tom Wood 
If the statute allowed the consumer to dispute the debt orally for purposes of both subsections (a)(3) and (a)(4), then there would be no argument about the current difference in language. But although this congruity would be helpful in settling this simmering dispute, a consumer would still be well advised to dispute the debt in writing in order to preserve a record of the communication between himself and the debt collector. After all, the consumer has the burden to show how and when he disputed the debt, and if he wants to make his case, the consumer will gravitate towards the written document rather than the spoken word.

The other alternative is to require a writing in all cases. This requirement may put many consumers at a disadvantage, for then they will not be able to send a message that there may be nothing to the collector's claim, without resorting to the formality of a writing. There may be very good reasons why a consumer may be unable to put his dispute in writing, and so it is in order to ask whether such a consumer should be denied the opportunity to raise questions about the debt. The consumer's challenge in this context should not be as daunting as when a debt collector gives an oral validation notice in its initial communication with the consumer. If a debt collector can orally convey all of the validation information in that communication, it seems that the consumer should have an easier time making the debt collector aware of his doubts about the debt. It is hard to accept that an oral notice is allowable to convey all of the information required under subsection (a), but a consumer is not able to use the same medium to convey just one message, that he disputes the debt. As a matter of principle, the sections should be consistent unless there is some good reason to make the distinction.

Pontiac-GMC, Inc., observed: "[S]ubsection (a)(3) provides some protection to those consumers who dispute a debt but are unable to do so in writing, perhaps the very consumers who are more likely to be unsophisticated." IPOO-1340-C-T/K, 2002 WL 31854892, at *27 (S.D. Ind. Nov. 4, 2002). Although the collector would not have to verify the debt to the consumer in writing at this stage or cease its collection activities, the consumer's intervention may at least encourage the collector's curiosity. See Vega v. Credit Bureau Enter., No. CIVA02V1550DGT KAM, 2005 WL 711657, at*7 (E.D.N.Y. Mar. 29, 2005) (noting that subsection (a)(3) does not impose a requirement that a consumer dispute the validity of a debt in writing). 


\section{UNFAIR OR UNCONSCIONABLE MEANS}

\section{A. The Language on the Envelope}

The statute prohibits a debt collector from using unfair or unconscionable means to collect a debt. ${ }^{382}$ A specific provision prevents a collector from using any language or symbol on an envelope when communicating with a consumer, except the collector's name. ${ }^{383}$ But even then, the collector's name cannot indicate that the collector is in the debt collection business. ${ }^{384}$ This provision has caused difficulties because its plain language allows on the envelope only the collector's address and the collector's business name if it does not reflect that the sender is in the collection business. If the statutory language is taken at face value, the use of any other language constitutes a violation. But the congressional purpose in prohibiting this type of conduct was to ensure that collectors would not use "symbols on envelopes indicating that the contents pertain to debt collection., 385 The collector cannot therefore embarrass the consumer by using collection language or symbols on an envelope.

The statute is quite firm in prohibiting any language or symbol other than that allowed. It is open to question whether Congress had to use such exclusionary language to make its point about ensuring that a debt collector would not open a consumer up to ridicule by letting others in on the collector's pursuit of the consumer. The effect of the plain language approach would have prevented the collector in Masuda v. Thomas Richards \& Co $^{386}$ from using the words "Personal and Confidential" on its envelope, and yet such language fulfilled the very objective that Congress intended to promote in $\S 1692 \mathrm{f}(8)$ by keeping confidential the communication between the collector and the consumer. The Masuda court viewed the terms on the envelope as "benign language" which was not covered by the statute. ${ }^{387}$ Such harmless words did not give a clue about the purpose of the communication. ${ }^{388}$

\footnotetext{
382. 15 U.S.C. $\S 1692 \mathrm{f}(2000)$.

383. Id. § $1692 \mathrm{f}(8)$. Section $1692 \mathrm{f}$ includes, without limitation, seven examples of unfair practices.

384. Id. The section provides that "a debt collector may use his business name if such name does not indicate that he is in the debt collection business." Id.

385. S. Rep. No. 95-382, at 8 (1977), reprinted in 1977 U.S.C.C.A.N. 1695, 1702.

386. 759 F. Supp. 1456 (C.D. Cal. 1991).

387. Id. at 1466 .

388. This was consistent with the purpose of $\S 1692 \mathrm{f}(8)$, that is, "to prevent debt collectors from
} 
In Peter v. GC Services L.P., ${ }^{389}$ the Fifth Circuit read $\S 1692 \mathrm{f}(8)$ as not producing an absurd result when read as a whole, and thus did not think it was necessary to go beyond the statutory text. ${ }^{390}$ Since the section contemplates use of the mails, the court felt comfortable with allowing language on an envelope that facilitated the envelope's movement through the mails, as long as such language did not violate the section's specific prohibitions. ${ }^{391}$ So the court had no objection to having the debtor's name and address or a postage stamp on the envelope, even though the section does not mention those items. ${ }^{392}$ But the court in Peter did not need to reach the issue about an implicit exemption for benign language since the collector's impersonation of the Department of Education was not benign. The court found a violation of $\S 1692 \mathrm{f}(8)$ because the collector had impersonated a public agency, and any implicit exception for benign language could not be stretched to accommodate that deception. ${ }^{393}$

A little later in Goswami v. American Collections Enterprise, Inc., the Fifth Circuit found the statutory provision ambiguous and looked beyond the statute's plain language to find a solution. ${ }^{394}$ In this case, the offending language on the envelope was "priority letter," a term that seemed normal within the mailing context, but which the consumer argued was impermissible under $\S 1692 \mathrm{f}(8) .{ }^{395}$ The court recognized that the statute was open to more than one reasonable interpretation. ${ }^{396}$ The court observed that the section could be read in isolation as prohibiting all language or markings other than the names and addresses of the

"using symbols on envelopes indicating that the contents pertain to debt collection." 759 F. Supp. at 1466 (citing S. Rep. No. 95-382, at 8, reprinted in 1977 U.S.C.C.A.N. at 1702) (emphasis omitted)).

389. 310 F.3d 344, 352 (5th Cir. 2002).

390. The court recognized that "the use of the mails" provision in 15 U.S.C. $§ 1692 \mathrm{f}(8)$ makes allowance for those items that are "necessary for an envelope to move through the mails." Id. at 351. Such items include "the name and address of the debtor [and] required postage ...." Id. So there was nothing in the statute to prevent a debt collector from placing a stamp on the envelope.

391. See id. (finding that $\$ 1692 \mathrm{f}(8)$ allowed items such as the name and address of a debtor and required postage because the items are necessary for an envelope to move through the mail).

392. Id.; see also Strand v. Diversified Collection Serv., Inc., 380 F.3d 316, 319 (8th Cir. 2004) (use of corporate logo with initials "DCS" and the terms "PERSONAL AND CONFIDENTIAL" on the envelope did not violate $\S 1692 f(8)$ ); Lindbergh v. Transworld Sys., Inc., 846 F. Supp. 175, 180 \& n.27 (D. Conn. 1994) (a blue stripe and the word "transmittal" on an envelope did not violate § 1692f(8)); Johnson v. NCB Collection Servs., 799 F. Supp. 1298, 1304-05 (D. Conn. 1992) (use of the "Revenue Department" was not a violation).

393. Peter, 310 F.3d at 352. One of the abuses that Congress had in mind was the impersonation of government officials in trying to collect a debt. S. Rep. No. 95-382, at 2, reprinted in 1977 U.S.C.C.A.N. at 1696.

394. 377 F.3d 488, 493 (5th Cir. 2004)

395. Id. at 491 .

396. Id. at 493 
parties. $^{397}$ On the other hand, it could be read in conjunction with its introductory language as prohibiting only such language or markings that are unfair or unconscionable because they humiliate or embarrass a consumer. ${ }^{398}$ In light of this ambiguity, the court reverted to legislative history and the FTC Staff Commentary in order to arrive at a sensible construction of the statute. ${ }^{399}$ It opted for the benign language exception because the term "priority letter" did not say anything about the consumer's delinquency, did not contribute to the consumer's embarrassment, and did not invade the consumer's privacy. ${ }^{400}$

\section{B. Taking or Threatening Nonjudicial Action}

Section $1692 \mathrm{f}(6)$ prohibits taking or threatening nonjudicial action to repossess property when there is no right to do so, ${ }^{401}$ and for purposes of that section, anyone whose principal business is the enforcement of security interests is regarded as a debt collector. ${ }^{402}$ A violation can occur if the repossessor breaches the peace because under the Uniform Commercial Code, the right to repossess no longer exists if a breach of the peace may ensue. ${ }^{403}$

A repossession often occurs when a creditor tries to enforce its security interest in a consumer's automobile. If the consumer has personal property inside the automobile at the time the repossessor takes the automobile, the consumer will usually complain about a violation of the FDCPA. ${ }^{404}$ However, the statute applies only when there is no right to property "claimed as collateral." ${ }^{405}$ Therefore, the statute applies to an automobile, which is the property the enforcer seeks to claim as

397. Id.

398. Id.

399. One of the unfair practices that Congress was interested in preventing was "using symbols on envelopes indicating that the contents pertain to debt collection." S. Rep. No. 95-382, at 8 (1977), reprinted in 1977 U.S.C.C.A.N. 1695, 1702.

400. See Goswami, 377 F.3d at 494 (citing Lindbergh v. Transworld Sys., Inc., 846 F. Supp. 175, 180 (D. Conn. 1994); Johnson v. NCB Collection Servs., 799 F. Supp. 1298, 1305 (D. Conn. 1992); Masuda v. Thomas Richards \& Co., 759 F. Supp. 1456, 1466 (C.D. Cal. 1991)) (finding that other courts have adopted a benign language exception to $\S 1692 \mathrm{f}(8)$ for terms like "priority letter").

401. 15 U.S.C. $\$ 1692 \mathrm{f}(6)$ (2000).

402. 15 U.S.C. $\$ 1692 \mathrm{a}(6)(2000)$.

403. U.C.C. § 9-609(b)(2) (2002).

404. See Nadalin v. Auto. Recovery Bureau, Inc., 169 F.3d 1084, 1084-85 (7th Cir. 1999) (discussing whether the incidental taking of personal property during an automobile repossession violated the FDCPA); Larranga v. Mile High Collection \& Recovery Bureau, Inc., 807 F. Supp. 111, 112-13 (D.N.M. 1992) (complaining that the incidental taking of personal property during an automobile repossession violated the FDCPA and was an act of conversion).

405. 15 U.S.C. $\S 1692 \mathrm{f}(6)(\mathrm{A})$. 
collateral for the creditor, but does not apply to any property that is inside. The nonjudicial action contemplated by $\S 1692 \mathrm{f}(6)$ relates to that collateral, and thus the FDCPA does not relate to any incidental possession of property that is not affected by the creditor's security interest. $^{406}$

Since an enforcer of a security interest is regarded as a debt collector only for the purpose of $\S 1692 \mathrm{f}(6),{ }^{407}$ it is not subject to other parts of the FDCPA. ${ }^{408}$ Congress made a distinction between debt collection and the enforcement of security interests for good reason. In the former case, Congress was concerned about the gross abuses which occur when consumers are unable to pay their debts because of unforeseen circumstances. $^{409}$ On the other hand, an enforcer of a security interest tries to recover property which is subject to a security interest and which is in the debtor's possession. The debtor's failure to return the property does not usually result from some misfortune, but rather from the debtor's deliberate decision to avoid turning over the property to the enforcer. ${ }^{410}$ Therefore, the harassment and unfair tactics which the FDCPA seeks to regulate in the case of debt collection do not relate to the actions of an enforcer of a security interest.

\section{CONCLUSION}

There is no doubt that Congress has gone a long way towards eliminating abusive debt collection practices. It has devised a statutory framework to protect the interests of collectors and consumers alike, with the expectation that debt collectors who comply with the statutory

406. See Larranga, 807 F. Supp. at 113 (finding that the incidental possession of personal property was not "property claimed as collateral" and therefore not under the FDCPA).

407. 15 U.S.C. $\S 1692 \mathrm{a}(6)$.

408. See Montgomery v. Huntington Bank, 346 F.3d 693, 700-01 (6th Cir. 2003) (concluding that a repossession agency is not a debt collector under FDCPA except under 1692f(6)); Seibel v. Soc'y Lease, Inc., 969 F. Supp. 713, 717 (M.D. Fla. 1997) (finding that only $\S 1692 f(6)$ applied to the repossession agency); Clark v. Auto Recovery Bureau, Inc., 889 F. Supp. 543, 546 (D. Conn. 1994) (finding that generally repossession companies are not within the scope of the FDCPA except under $\S 1692 \mathrm{f}(6))$; Jordan v. Kent Recovery Servs., Inc., 731 F. Supp. 652, 657 (D. Del. 1990) (finding that a repossession agency was outside the scope of FDCPA except for $\S 1692 \mathrm{f}(6)$ ); FTC Staff Commentary, supra note 11, at 50,108 (finding that parties who are only debt collectors under $\S 1692 \mathrm{f}(6)$ are "subject only to that provision and not to the rest of FDCPA").

409. The Senate Report reflected the findings of the National Commission on Consumer Finance: "[T]he vast majority of consumers who obtain credit fully intend to repay their debts. When default occurs, it is nearly always due to an unforeseen event such as unemployment, overextension, serious illness, or marital difficulties or divorce." S. Rep. No. 95-382, at 3 (1977), reprinted in 1977 U.S.C.C.A.N. 1695, 1697.

410. Jordan, 731 F. Supp. at 658. 
requirements will not suffer any competitive disadvantage in the marketplace. ${ }^{411}$ Nevertheless, like everything else, there is always room for improvement, and the FDCPA is no exception.

In its effort to promote consistency and simplicity in the FDCPA, Congress has sometimes failed to relate the definitions to other parts of the statute, thus creating some doubt about congressional intent. The term "communication" has caused problems because the definition is simply "the conveying of information regarding a debt ... through any medium." 412 There is no special accommodation for certain legal documents like a summons or complaint, ${ }^{413}$ but this does not mean that a collector is helpless in the face of this general definition of "communication." A debt collector can avoid problems by sending its validation notice at least thirty days before attempting suit, thus creating no conflict between the notice and the documents relating to the lawsuit. ${ }^{414}$ This should leave no doubt in a consumer's mind that the FDCPA's requirements are separate from court-related requirements, thus avoiding any confusion that might normally arise when the two procedures clash and the consumer does not know what to do. If the collector does not want to wait thirty days before suing, the collector should provide explanatory language in its collection notice that a summons and complaint are different from a validation notice and that the consumer must follow the procedures that are judicially mandated for the legal documents. ${ }^{415}$

411. See 15 U.S.C. $\S 1692$ (e) (2000) (stating that the purpose of the FDCPA is to ensure that debt collectors who refrain from using abusive debt collection practices are not competitively disadvantaged).

412. 15 U.S.C. $§ 1692 \mathrm{a}(2)$ (2000).

413. In its first advisory opinion, the FTC stated that "[i]f an attorney debt collector has had no prior communications with a consumer before serving a summons or other court document on the consumer, that document would constitute the 'initial communication' with the consumer if it conveys information regarding a debt." Advisory Opinion, supra note 23. Good faith reliance on an advisory opinion excuses liability. See 15 U.S.C. $\S 1692 \mathrm{k}(\mathrm{e})$ (2000) (stating no provision of the FDCPA imposing any liability shall apply to any act done or omitted in good faith in conforming with an advisory opinion of the commission).

414. See Thomas v. Law Firm of Simpson \& Cybak, 392 F.3d 914, 919 (7th Cir. 2004) (noting that a creditor can have its initial communication with the debtor upwards of thirty days before beginning the litigation process).

415. The court in Thomas suggested the following language:

This advice pertains to your dealings with me as a debt collector. It does not affect your dealings with the court, and in particular it does not change the time at which you must answer the complaint. The summons is a command from the court, not from me, and you must follow its instructions even if you dispute the validity or amount of the debt. The advice in this letter also does not affect my relations with the court. As a lawyer, I may file papers in the suit according to the court's rules and the judge's instructions.

392 F.3d at 919-20.

This is not the first model letter to originate from the Seventh Circuit. See Miller v. McCalla, 
It is regrettable that the validation section has caused debt collectors such agony. Although it is designed to ensure that a collector will inform the consumer of the basic details of the transaction and of the right to dispute the debt, ${ }^{416}$ debt collectors have fallen prey to their own recovery strategies. But it is not entirely their fault because Congress has sent mixed messages with the validation provision. If Congress wanted to give a consumer a genuine chance to verify the validity of the debt, it would not simultaneously allow the collector to continue badgering the consumer in the interim. The collector is left to its own devices to craft acceptable language that discharges its statutory responsibility, but at the same time it pressures the consumer about the debt. ${ }^{417}$ The validation section legitimizes these dual interests and clothes them with respectability. It is as if Congress wanted to give a consumer some small measure of protection without giving him too much leeway to question the debt.

If the consumer has the courage to dispute the debt, the collector must suspend its collection activities until it verifies the debt. ${ }^{418}$ It is noteworthy that the collector does not have to tell the consumer that this is what will happen if the consumer disputes the debt. ${ }^{419}$ It is but another

Raymer, Padrick, Cobb, Nichols, \& Clark, L.L.C., 214 F.3d 872, 876 (7th Cir. 2000) (providing a model letter that satisfies the debt collector's duty to state the amount of debt in cases where the amount varies daily); Bartlett v. Heibl, 128 F.3d 497, 501-02 (7th Cir. 1997) (providing form letter for debt collector seeking to inform debtor of collector's intention to resort to legal action before expiration of thirty-day window in which debtor may seek verification of debt pursuant to FDCPA).

416. The Senate Report captured the basic purpose of the validation section in these words: "This provision will eliminate the recurring problem of debt collectors dunning the wrong person or attempting to collect debts which the consumer has already paid." S. Rep. No. 95-382, at 4 (1977), reprinted in 1977 U.S.C.C.A.N. 1695, 1699.

417. See Durkin v. Equifax Check Servs., Inc., 406 F.3d 410, 412 (7th Cir. 2005) (involving creditor who sent initial letter to debtor plus two follow up letters); Shimek v. Forbes, 374 F.3d 1011,1012 (11th Cir. 2004) (involving collector filing a lien at the same time it sent dunning letter to consumer); McStay v. I.C. Sys., Inc., 308 F.3d 188, 189 (2d Cir. 2002) (involving dunning letter stating that if account was not paid in thirty days debtor would be reported to credit reporting agencies); Renick v. Dun \& Bradstreet Receivable Mgmt. Servs., 290 F.3d 1055, 1057 (9th Cir. 2002) (involving second notice to debtor including instruction that debtor use tear-off portion to send payment "today"); Wilson v. Quadramed Corp., 225 F.3d 350, 351 (3d Cir. 2000) (involving letter which notifed debor that account had been placed for "immediate collection" and that it shall afford the opportunity to pay the bill immediately); Johnson v. Revenue Mgmt. Corp., 169 F.3d 1057, 1059 (7th Cir. 1999) (involving letter demanding that debtor pay debt promptly or face legal action or reporting to credit bureau); Savino v. Computer Credit, Inc., 164 F.3d 81, 84 (2d Cir. 1998) (involving demand for immediate payment on front of letter without explaining demand did not override consumer's rights under FDCPA to seek debt validation from creditor); United States v. Nat'l Fin. Servs., Inc., 98 F.3d 131, 133 (4th Cir. 1996) (involving letter stating that the debtor's account would be transferred to an attorney if the amount was unpaid after the deadline date and reminding debtor that the debtor's attorney would also want to be paid).

418. 15 U.S.C. $\S 1692 \mathrm{~g}(\mathrm{~b})(2000)$.

419. Despite the lack of this requirement, the model letter in Bartlett v. Heibl does tell the consumer that the debt collector must suspend its collection activities. 128 F.3d at 502; see also 
example of the statute giving some halfway remedy, but not really wanting to go the whole way by imposing an obligation on the creditor to advise the consumer of the ensuing suspension of collection activities. One suspects that it would be better for the statute to prescribe a cessation period during which the consumer can challenge the debt without fear of being pursued by the collector. ${ }^{420}$ It is only then that a consumer can truly enjoy his statutory option; otherwise it is only a feeble measure that hardly restrains the collector.

On another front, Congress should require the validation notice to be in writing if it wants to ensure that the consumer will assimilate the information. $^{421}$ There is nothing in the statute that requires an initial communication to be written, and thus the collector may include the validation information in such a communication. It cannot be seriously argued that a consumer can obtain effective notice of the details in this manner. A consumer must be able to act on the information contained in the validation notice, and he will be unable to do so if he cannot recall the statutory rights which the collector read off to him in its initial communication.

Finally, some change would be welcome in the language of $\S$ $1692 \mathrm{f}(8)$ to address the problem that Congress had in mind. Surely it

NAT'L CONSUMER LAW CTR., supra note 33, § 5.7.3.4, at 239 (stating that the FDCPA does not require that consumers be notified that debt collectors, after receiving a timely written dispute or request for validation, must suspend collection until the collectors verify the debt).

420. This approach would convert the current thirty-day dispute period into a true grace period. The FTC and the cases agree that the statute does not currently support a grace period. See Smith v. Computer Credit, Inc., 167 F.3d 1052, 1055 (6th Cir. 1999) (stating that a collection agency does not have to cease collection efforts to comply with the Act but must ensure that its efforts do not threaten a consumer's right to dispute the validity of the debt); Bartlett, 128 F.3d at 501 (noting a debt collector must cease his efforts at collection only between the time of consumer's request for verification of the debt and the collector's verification to the debtor); 2005 FTC ANN. REP., supra note 309, at 14-15 (stating the Commission has consistently taken the position that collection efforts can continue during the thirty-day period if the consumer does not dispute the debt in writing or request verification, but noting that some continue to argue that the thirty-day period is a grace period).

421. Although the FTC is concerned with the clarity of a written validation notice, it has not dealt with the possibility of having an oral validation notice in light of a possible initial communication that need not be written. The FTC recommended in its 2005 annual report that "Congress amend Section 809 of the FDCPA to make explicit the standard for clarity to be applied to the consumer notice required by that section." 2005 FTC ANN. REP., supra note 309, at 13 (footnote omitted). However, the consumer notice may be conveyed in the collector's initial communication, but that communication need not be in writing. Compare 15 U.S.C. $§ 1692 \mathrm{~g}(\mathrm{a})$ (2000) (stating within five days after initial communication the debt collector must send the consumer written notice containing certain information unless the information was contained in the intial communication), with 15 U.S.C. $\S 1692 \mathrm{a}(2)$ (2000) (defining the term "communication" to include the conveying of information through any medium). So the FTC's observation that "Section 809(a) requires debt collectors to send a written notice to each consumer within five days after first contacting the consumer" does not address the method of the first contact. 2005 FTC ANN. REP., supra note 309 , at 13 . 
must have been to spare consumers the embarrassment of having their private business exposed to the world at large. When the section forbade a collector from using any language on an envelope other than a debt collector's address, it went overboard to achieve its objective. Courts were left, therefore, to apply the section sensibly, even though Congress must have known what it was doing when it used the word "any" in trying to control a collector's conduct. ${ }^{422}$ Surely it was possible for the drafters to use limiting language that had some relation to the objective that Congress sought to achieve. The prohibition should relate to the debt which the collector is trying to collect, but language which gives no clue about the business between the collector and the consumer should not be within the purview of the section.

422. See Strand v. Diversified Collection Serv., Inc., 380 F.3d 316, 319 (8th Cir. 2004) (refusing to apply a strict reading of $\S 1692 \mathrm{f}(8)$ and thus exempting benign words and symbols provision because a strict reading would lead to bizarre and impracticable consequences); Goswami v. Am. Collections Enter., Inc., 377 F.3d 488, 493-94 (5th Cir. 2004) (using an FTC comment and legislative history to conclude the FDCPA does not bar innocuous priority letter markings); Peter $\mathrm{v}$. GC Servs., L.P., 310 F.3d 344, 351 (5th Cir. 2002) (holding that $\S 1692 \mathrm{f}(8)$ does not prohibit the placing of a stamp or the debtor's address on an envelope); Lindbergh v. Transworld Sys., Inc., 846 F. Supp. 175, 180 (D. Conn. 1994) (refusing to apply a mechanical interpretation of $\S 1692 \mathrm{f}(8)$ ); Johnson v. NCB Collection Servs., 799 F. Supp. 1298, 1305 (D. Conn. 1992) (holding that the use of "Revenue Department" in the return address of a collection notice is not the type of abusive collection practice the FDCPA was intended to affect); Masuda v. Thomas Richards \& Co., 759 F. Supp. 1456, 1466 (C.D. Cal. 1991) (refusing to apply § 1698f(8) literally in every case). 
$* * *$ 